\title{
Characterization of Fill Deposits in the Calumet Region of Northwestern Indiana and Northeastern Illinois
}

U.S. GEOLOGICAL SURVEY

Water-Resources Investigations Report 96-4126

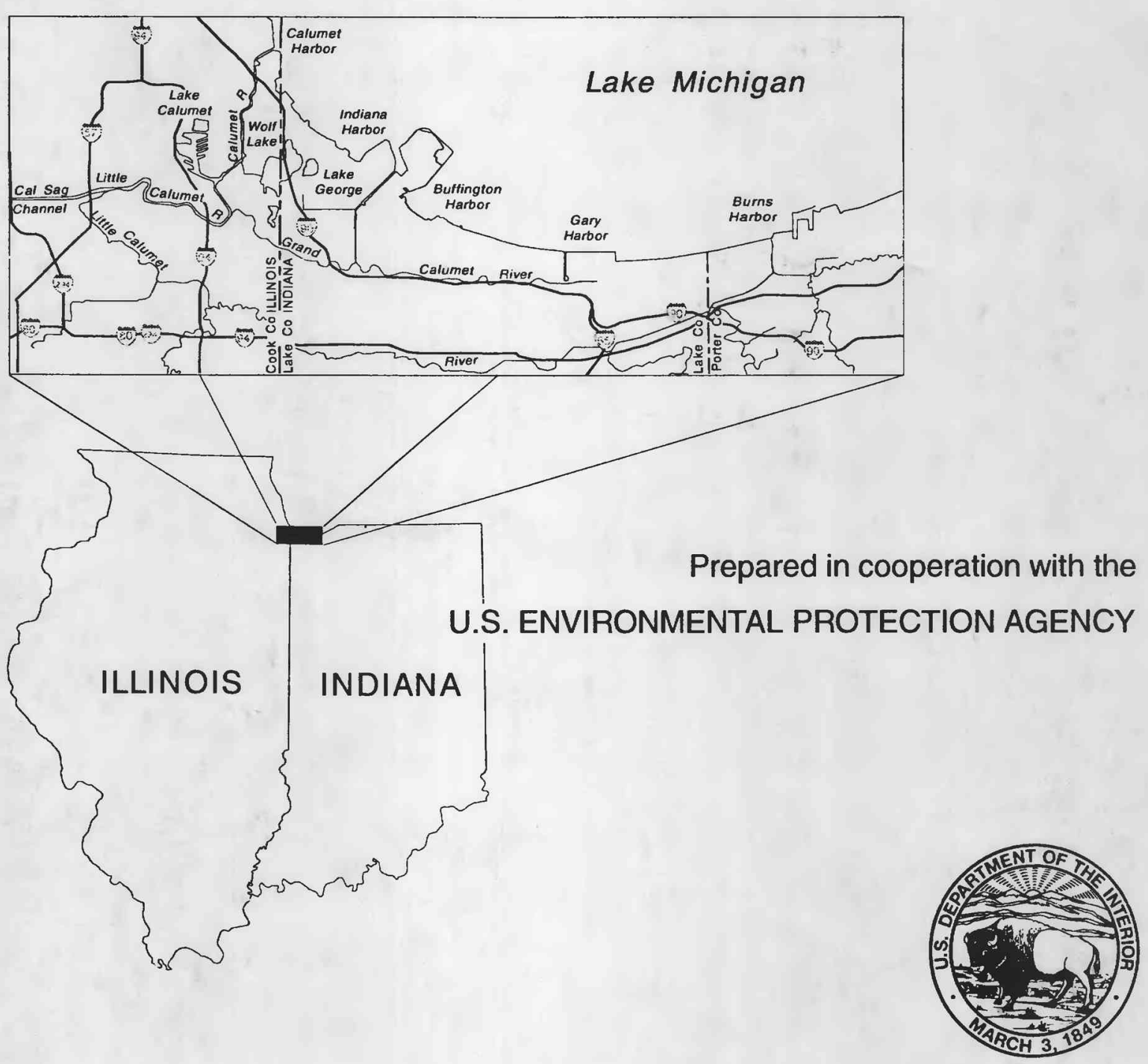




\section{Characterization of Fill Deposits in the Calumet Region of Northwestern Indiana and Northeastern Illinois}

By ROBERT T. KAY, THEODORE K. GREEMAN, RICHARD F. DUWELIUS, ROBIN B. KING, and JOHN E. NAZIMEK, U.S. Geological Survey, and DAVID M. PETROVSKI, U.S. Environmental Protection Agency

U.S. GEOLOGICAL SURVEY

Water-Resources Investigations Report 96-4126

Prepared in cooperation with the

U.S. ENVIRONMENTAL PROTECTION AGENCY

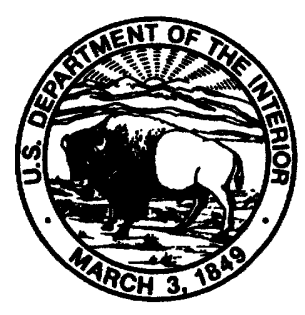




\section{U.S. DEPARTMENT OF THE INTERIOR \\ BRUCE BABBITT, Secretary}

\section{U.S. GEOLOGICAL SURVEY}

Gordon P. Eaton, Director

The use of trade, product, industry, or firm names in this report is for identification or location purposes only, and does not constitute endorsement of products by the U.S. Geological Survey, nor impute responsibility for any present or potential effects on the natural resources.

For additional information write to:

District Chief

U.S. Geological Survey

221 N. Broadway

Urbana, IL 61801

(217) 344-0037

District Chief

U.S. Geological Survey 5957 Lakeside Boulevard Indianapolis, IN 46278-1996
Copies of this report can be purchased from:

\section{U.S. Geological Survey}

Branch of Information Services

Box 25286

Denver, CO 80225-0286 


\section{CONTENTS}

Abstract
Introduction
Purpose and Scope
Description of the Study Area
Physiography and Climate
Development of the Calumet Region

\section{PLATES}

[Plates are in pocket]

1. Map showing location and thickness of fill deposits, Calumet region of northwestern Indiana and northeastern Illinois.

2. Map showing type of fill deposits, Calumet region of northwestern Indiana and northeastern Illinois.

3. Map showing approximate date of initial deposition of fill, Calumet region of northwestern Indiana and northeastern Illinois.

\section{FIGURES}

1-9. Maps showing:

1. Location of study area, political boundaries, and surface-water bodies, Calumet region of northwestern Indiana and northeastern Illinois

2. Land use, Calumet region of northwestern Indiana and northeastern Illinois

3. Location of important topographic features, Calumet region of northwestern Indiana and northeastern Illinois.

4. Direction of surface-water flow, Calumet region of northwestern Indiana and northeastern Illinois, June 23-25, 1992.

5. Surficial geology, Calumet region of northwestern Indiana and northeastern Illinois.

6. Thickness of sand deposits that compose the Calumet aquifer, Calumet region of northwestern Indiana and northeastern Illinois.

7. Water-table configuration, Calumet region of northwestern Indiana and northeastern Illinois, June 23-25, 1992

8. Physiographic features, surface-water bodies, and selected political boundaries prior to 1840 , Calumet region of northwestern Indiana and northeastern Illinois.

9. Location of areas with similar spectral signatures as areas known to have slag at land surface, Calumet region of northwestern Indiana and northeastern Illinois. 


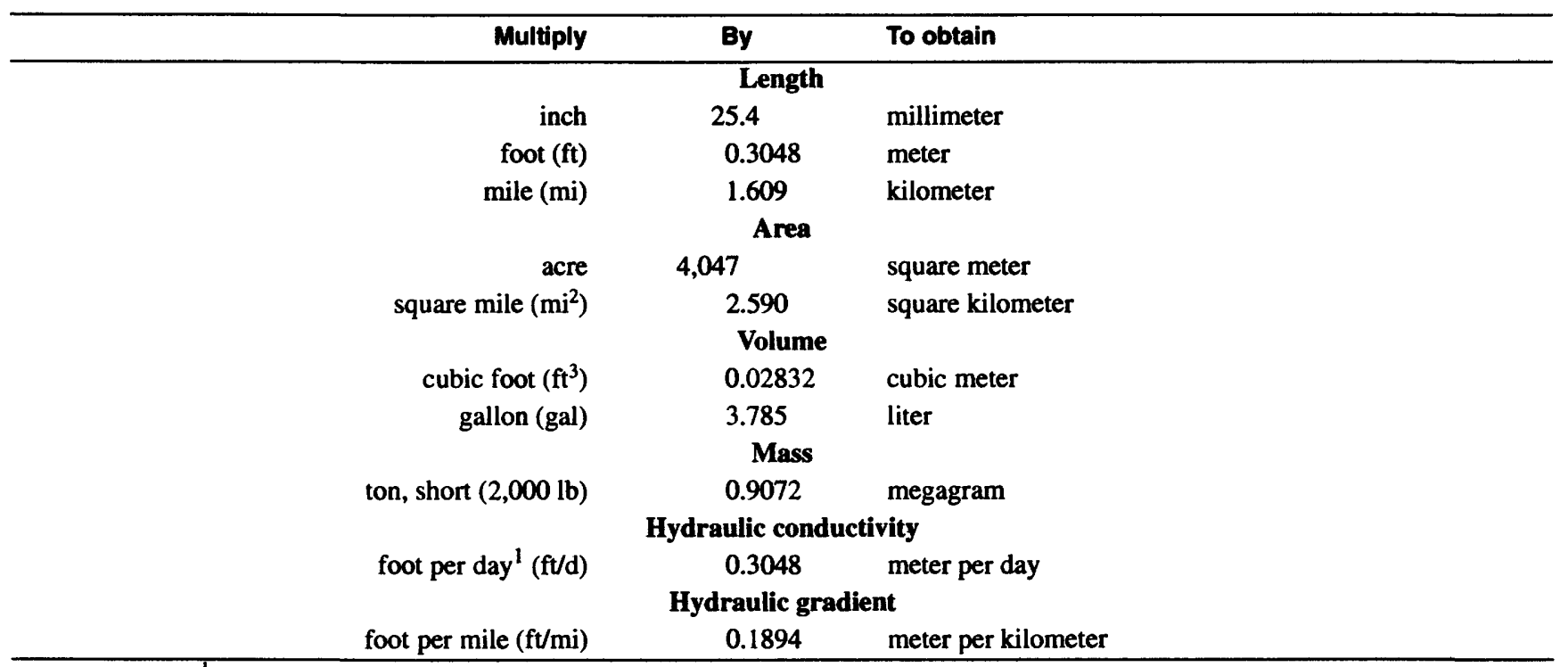

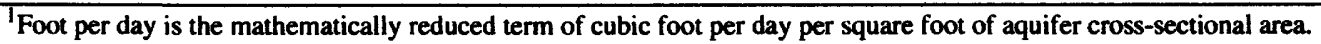

Temperature in degrees Celsius $\left({ }^{\circ} \mathrm{C}\right)$ may be converted to degrees Fahrenheit $\left({ }^{\circ} \mathrm{F}\right)$ as follows:

$$
{ }^{\circ} \mathrm{F}=9 / 5\left({ }^{\circ} \mathrm{C}\right)+32
$$

Sea level: In this report, "sea level" refers to the National Geodetic Vertical Datum of 1929 (NGVD of 1929)-a geodetic datum derived from a general adjustment of the first-order level nets of both the United States and Canada, formerly called Sea Level Datum of 1929.

\begin{abstract}
Abbreviated water-quality units used in this report: Chemical concentration is given in metric units. Chemical concentration is given in micrograms per liter $(\mu \mathrm{g} / \mathrm{L})$ or milligrams per kilogram ( $\mathrm{mg} / \mathrm{kg}$ ). Micrograms per liter is a unit expressing the concentration of chemical constituents in solution as weight (micrograms) of solute per unit volume (liter) of water. One thousand micrograms per liter is equivalent to one milligram per liter. Milligrams per kilogram are in units expressing the concentration of chemical constituents in solution as mass (milligrams) of constituent per unit mass (kilogram) of a dry sample.
\end{abstract}




\title{
Characterization of Fill Deposits in the Calumet Region of Northwestern Indiana and Northeastern Illinois
}

\author{
By Robert T. Kay, Theodore K. Greeman, Richard F. Duwelius, Robin B. King, \\ John E. Nazimek, and David M. Petrovski
}

\section{Abstract}

In October 1993, the U.S. Geological Survey, in cooperation with the U.S. Environmental Protection Agency, began a study of the fill deposits in the Calumet region of northwestern Indiana and northeastern Illinois. Fill in this area is a mixture of steel-industry wastes, other industrial waste, municipal solid waste, dredging spoil, construction debris, ash, cinders, natural materials, and biological sludge. Fill deposits are concentrated along Lake Michigan; from the Lake Calumet area to the east of the Indiana Harbor Canal; along the Calumet, Little Calumet, and Grand Calumet Rivers; and along the Calumet Sag Channel. Industrial wastes and municipal solid wastes are used as fill near Lake Calumet. Steel-industry wastes, primarily slag, are used as fill along Lake Michigan, Wolf Lake, Lake George, parts of Lake Calumet, and parts of the Calumet and Little Calumet Rivers. Dredging spoil is located along the rivers, and in abandoned river channels, landfills, and tailing ponds. Cinders, ash, construction debris, and natural materials are scattered throughout the area.

Currently (1996), fill covers about 60.2 square miles of the study area. A total volume of about $2.1 \times 10^{10}$ cubic feet of fill was calculated to be present in the Calumet region. Most of this fill is steel-industry waste.

Fill deposition in the study area has been essentially continuous from about 1870 to the present. Fill deposited before 1964 was used as foundation for streets and railroad tracks, to create land for industrial expansion, and to dispose of waste material. Much of the fill deposited after 1964 was disposed of in landfills designed to minimize environmental effects.

Industrial wastes, municipal solid wastes, steel-industry wastes, and, perhaps, dredging spoil can be associated with increased concentrations of volatile and semivolatile organic compounds, pesticides, cyanide, metals, or major ions in ground water in this area. Construction debris, ash, cinders, and natural fill may be associated with increased concentrations of major ions in ground water.

\section{INTRODUCTION}

The Calumet region of northwestern Indiana and northeastern Illinois has changed dramatically during the past 150 years. This region, at the southern end of Lake Michigan, was once a wilderness of dunes, lakes, and marshes. By 1840 , the wilderness began to disappear as railroads pushed through the dunes and marshes, and settlements were established in the region. By 1900 , the advantage of bulk transport by ship on Lake Michigan and the construction of harbors created the proper conditions for industrial development of the area.

The industrialization and consequent urbanization of the Calumet region resulted in the destruction or alteration of many of the dunes, lakes, and marshes in an effort to make land suitable for industrial and residential expansion. A variety of materials, including natural materials, industrial wastes, construction debris, ash and cinder, and municipal 
solid waste, were used as fill to elevate the land surface above the level of the lakes and marshes. Between 1840 and the latter half of the twentieth century, disposal of fill material was essentially unregulated. Records of fill disposal were typically not kept, and the locations of many areas of fill deposition are no longer obvious. Some of these fill materials may be sources of contamination to surface water and ground water.

In October 1993, the U.S. Geological Survey (USGS), in cooperation with the U.S. Environmental Protection Agency (USEPA), began a study of the fill deposits in the Calumet region of northwestern Indiana and northeastern Illinois (fig. 1). The study was done to determine the location, thickness, volume, type, and approximate date of deposition of the fill deposits in this area and to generally characterize the relation between fill type and ground-water quality. This information can be used to focus future investigations and to assess soil-, sediment-, surface-water, and ground-water-remediation options.

The study was divided into four major components: (1) Compilation and analysis of historical maps, aerial photographs, and satellite images; (2) compilation and analysis of lithologic, hydrologic, and water-quality data; (3) field verification of type and location of fill deposits; and (4) drilling of soil borings. Compilation and analysis of topographic maps and aerial photographs helped determine the location, thickness, and approximate date of deposition of the fill. Analysis of satellite images was used to determine the location of slag fill. Compilation and analysis of lithologic data were done to determine the type, thickness, and location of the fill. Lithologic and hydrologic data, in conjunction with water-quality data, were analyzed to characterize the hydrology of the fill and the general relation between fill type and ground-water quality. Field verification was done to ensure the accuracy of interpretations made from analysis of the topographic maps, aerial photographs, and satellite images. Soil borings and soil probes were used to determine the type or thickness of the fill in areas where other forms of data were unavailable or did not clearly indicate fill type.

\section{Purpose and Scope}

This report describes the results of a study designed to characterize the fill deposits in a heavily industrialized area of northwestern Indiana and northeastern Illinois. Lithologic logs, topographic maps, aerial photographs, and satellite images were used to determine the location, thickness, volume, type, and approximate date of deposition of fill deposits on a regional basis. The report also describes the chemical constituents detected in ground water associated with the various fill types in the study area. Detailed, site-specific characterization of fill and its effect on ground-water quality is beyond the scope of this study.

\section{Description of the Study Area}

The study area is located in the Calumet region of northwestern Indiana and northeastern Illinois and includes parts of Porter and Lake Counties in Indiana and Cook County in Illinois (fig. 1). The study area is bounded by the southern limit of the Little Calumet River and Interstates 80/94 and 294 to the south, Crawford Avenue to the west, Mineral Springs Road to the east, and 80th Street and Lake Michigan to the north. This area is opproximately $240 \mathrm{mi}^{2}$ in size.

Land use in the study area is primarily residential and industrial (fig. 2). Large tracts of open water, natural land, and land for the processing and disposal of wastes also are present. Much of the land along Lake Michigan and the Calumet River is or was used for steel production. Land used by the petrochemical industry for tank farms and petroleum refining is located south and west of the steel mills in Indiana and at scattered locations along the Grand Calumet River, the Calumet Sag Channel, and Lake Calumet in Illinois. A variety of other industrial activities, including automobile assembly, scrap processing, and chemical manufacturing, take place in the study area. Several large sanitary landfills and wastewatertreatment plants also are present.

\section{Physiography and Climate}

The study area is in the Eastern Lake Section of the Central Lowland physiographic province defined by Fenneman (1938). The Indiana part is in the Calumet Lacustrine Plain subdivision of the Northern Moraine and Lake Region defined by the Indiana Geological Survey (Malott, 1922, p. 113; Schneider, 1966, p. 50). The Calumet Lacustrine Plain extends westward into Illinois where it is called the Chicago 
Lake Plain subsection of the Great Lakes Section of the Central Lowland physiographic province as defined by the Illinois State Geological Survey (Leighton and others, 1948, p. 21).

The Calumet region has a generally flat land surface largely covered by rivers, lakes, and wetlands. This flat surface is broken up by topographically elevated features including dunes, beach ridges, morainal islands, and bedrock mounds. The Tolleston Beach Ridge rises over $30 \mathrm{ft}$ above the surrounding area and trends east-west through the southern part of the study area (fig. 3). Several hundred smaller sandy beach ridges and dunes with a height of 5-50 ft above the surrounding wetlands are or were present north of the Tolleston Beach Ridge. These ridges and dunes roughly parallel the shoreline of Lake Michigan (Salisbury and Alden, 1899, p. 58). In addition to the dunes and beach ridges, Blue Island, a north-southtrending morainal island in the western part of the study area, and Stony Island, a bedrock mound in the northern part of the study area, rise above the flat land surface.

The climate in this area is classified as temperate continental, with a mean annual temperature of about $10^{\circ} \mathrm{C}$ and a mean annual precipitation of 35.7 inches (National Oceanic and Atmospheric Administration, 1991). More than half of the average annual precipitation falls from April 1 through August 31. Although large variations in precipitation and temperature may occur in any year, summers generally are hot and humid, whereas winters are cold. Lake Michigan has a moderating local effect on temperature.

\section{Hydrogeologic Setting}

The three hydrologic units of concern to this investigation are surface water, the Calumet aquifer, and the confining unit. The characteristics of these units will affect the transport and fate of the constituents dissolved in surface and ground water.

The largest lakes in the study area are Lake Michigan, Lake Calumet, Wolf Lake, and Lake George (fig. 4). Lake Michigan has a substantial effect on the surface- and ground-water hydrology of the study area. Fluctuations in the stage of Lake Michigan can cause large (up to $5 \mathrm{ft}$ ) changes in ground-water and surface-water levels (Greeman, 1995, p. 27) and affect flow between surface water and ground water.
With the exception of Lake Michigan, the lakes in the study area are partially or completely isolated from the surface-water-flow system. Water is delivered to Lake Calumet through manmade drainage channels, storm sewers, and recharge from ground water. Lake Calumet receives only small amounts of natural surface-water drainage (Ross and others, 1988, p. 46). Water originally pumped from Lake Michigan is discharged to Wolf Lake by industries located along the northern arm of the lake. Squaw Creek, a shallow, manmade drainage ditch, connects Wolf Lake to the Calumet River (fig. 4). Lake George and the smaller lakes scattered throughout the Calumet region are located either in topographic depressions between dune and beach ridge deposits or in pits created by mining of sand and clay. Lake George and almost all of the smaller lakes are hydraulically isolated from the overall surface-water-flow system. The hydraulic isolation of the lakes in the study area indicates that any compounds released to the lakes will not easily be dispersed by flow or diluted with freshwater.

The Grand Calumet, Little Calumet, and Calumet Rivers are the principal drainages in the study area (fig. 4). Surface-water flow in the Grand Calumet and Little Calumet Rivers is to Lake Michigan through Burns Harbor or the Indiana Harbor Canal in most of Indiana. Surface-water flow in the Grand Calumet and Little Calumet Rivers is to the Calumet Sag Channel in the western part of Indiana and most of Illinois. Surface-water flow of the Calumet River is typically toward Lake Calumet or Lake Michigan. The direction of flow in the Calumet River is dependent on the stage of Lake Michigan, Squaw Creek, and operations at the O'Brien Lock and Dam.

Surface-water gradients on the Calumet and Grand Calumet Rivers and the Indiana Harbor Canal averaged less than $0.5 \mathrm{ft} / \mathrm{mi}$ in June 1993 (Kay and others, 1996, p. 41). Surface-water gradients on the Little Calumet River averaged $0.7 \mathrm{ft} / \mathrm{mi}$ in June 1993 (Kay and others, 1996, p. 41). The low hydraulic gradients on the rivers indicate sluggish flow not easily capable of dispersing anthropogenic compounds discharged to the rivers. Flow of the Calumet and Grand Calumet Rivers and the Indiana Harbor Canal has historically been so low that their channels required dredging to maintain the navigability of the canal and the flow of the rivers (Colten, 1985, p. 23).

The surficial geology in the study area consists primarily of glacial and lacustrine sand, silt, and clay deposits of Wisconsinan and Recent age (fig. 5). 


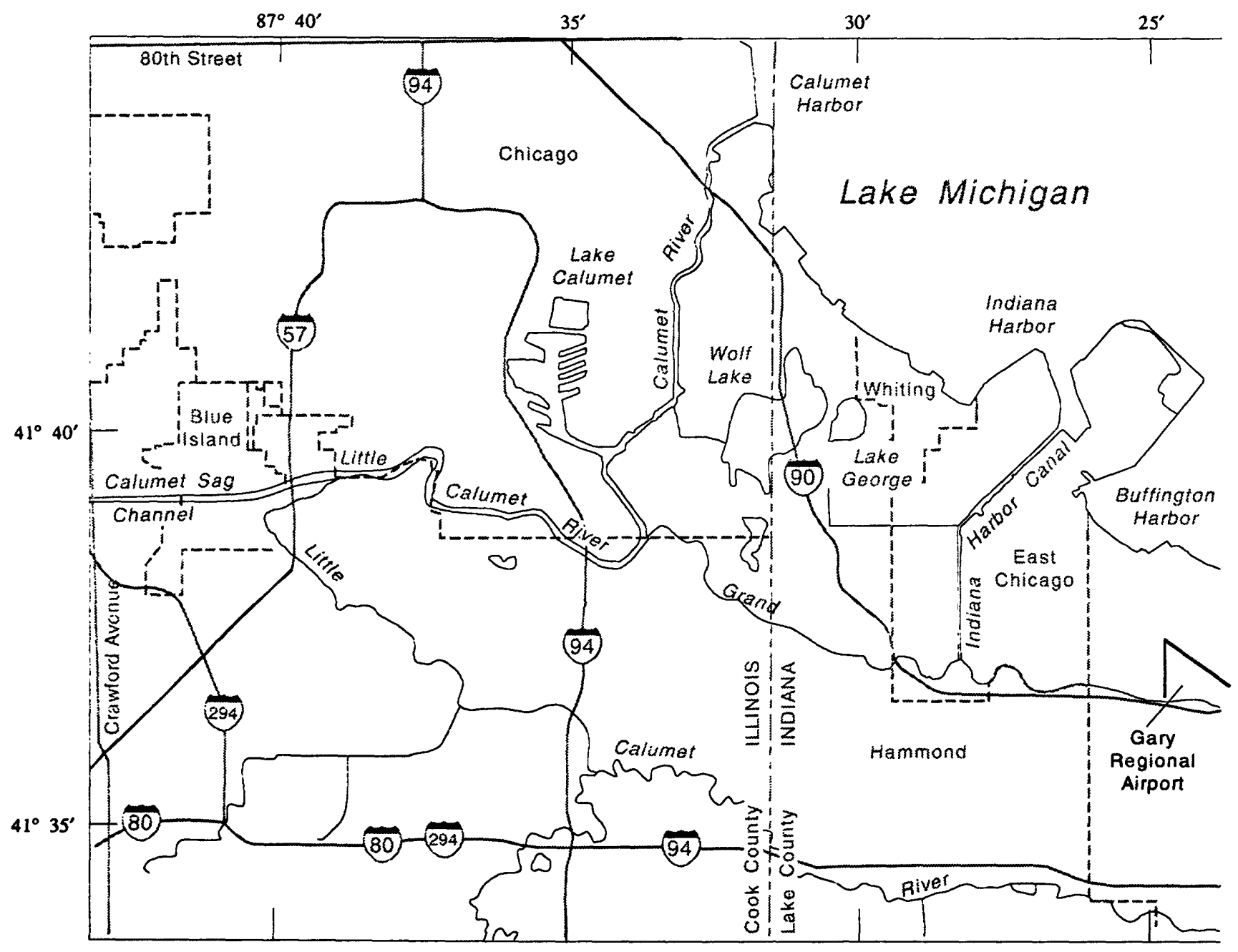

\section{EXPLANATION}

- POLITICAL BOUNDARY

Figure 1. Location of study area, political boundaries, and surface-water bodies, Calumet region of northwestern Indiana and northeastern Illinois. 


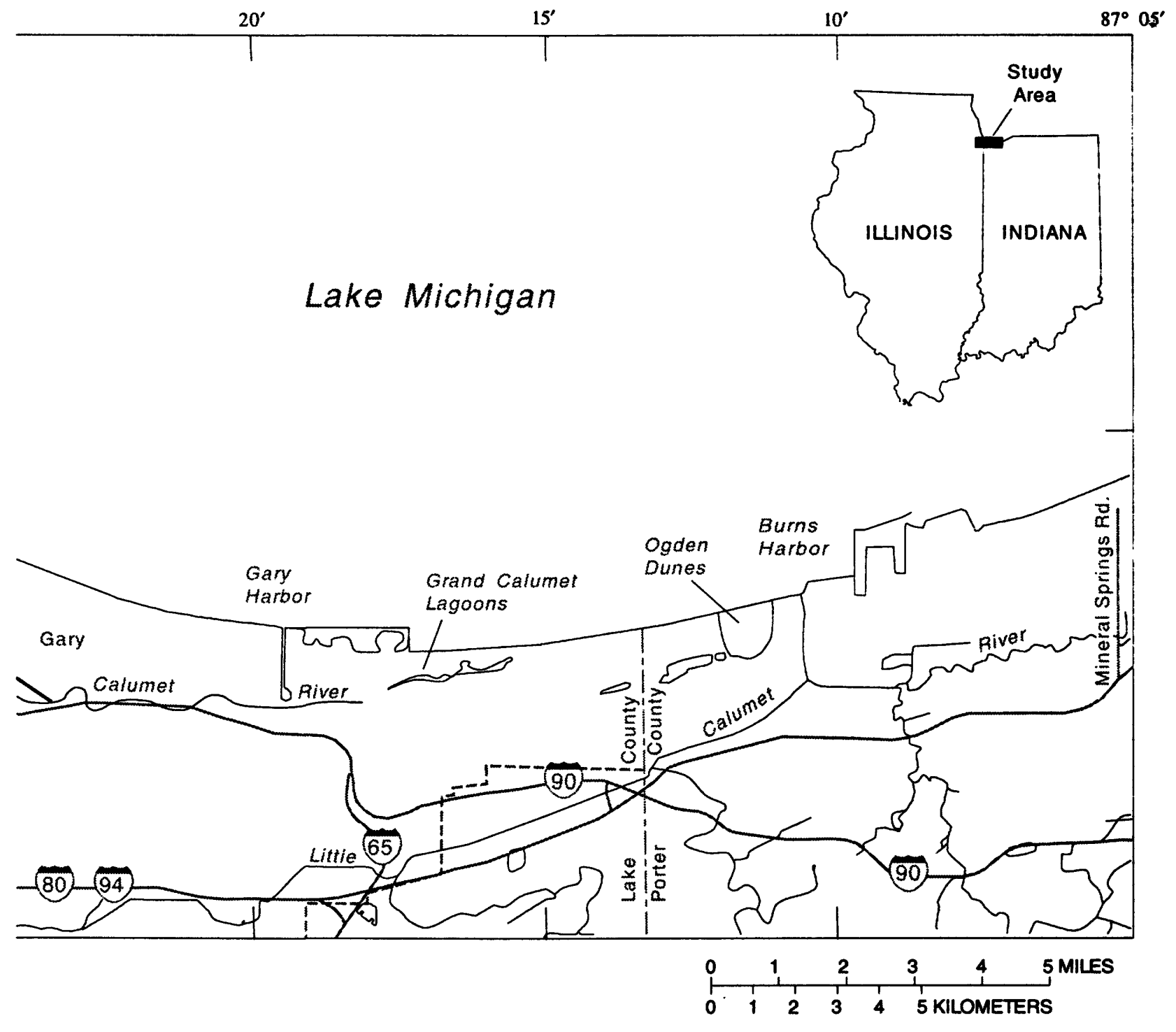

Figure 1. Continued. 


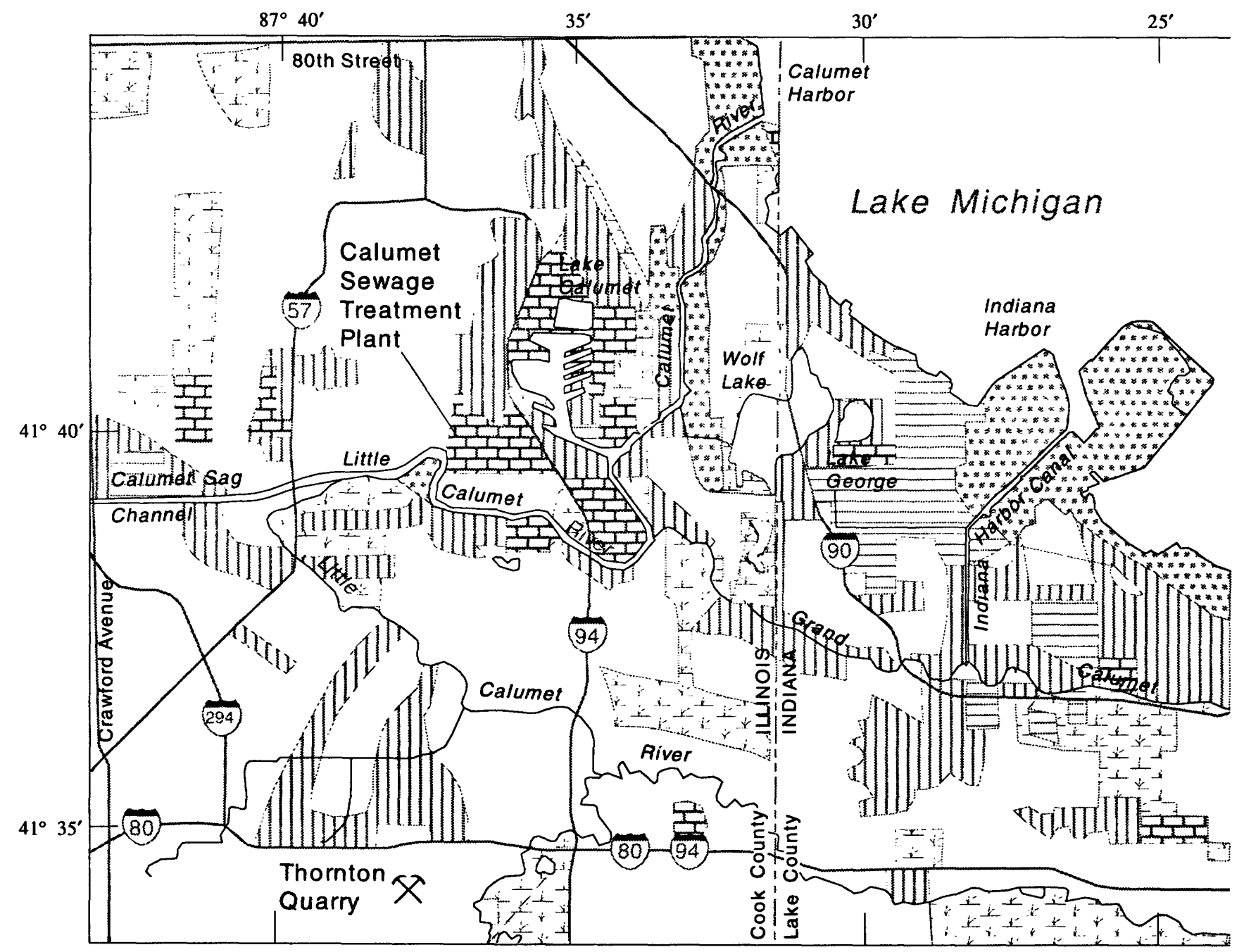

\section{EXPLANATION}

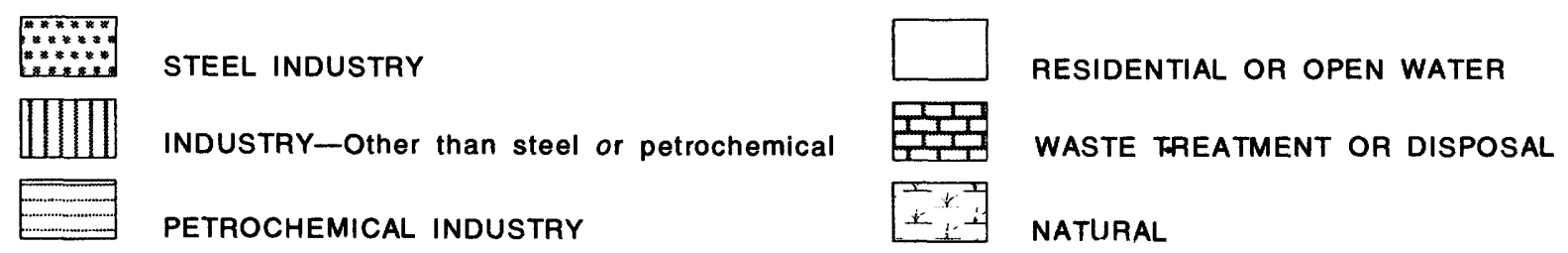

Figure 2. Land use, Calumet region of northwestern Indiana and northeastern Illinois (modified from Kay and others, 1996, fig. 2). 


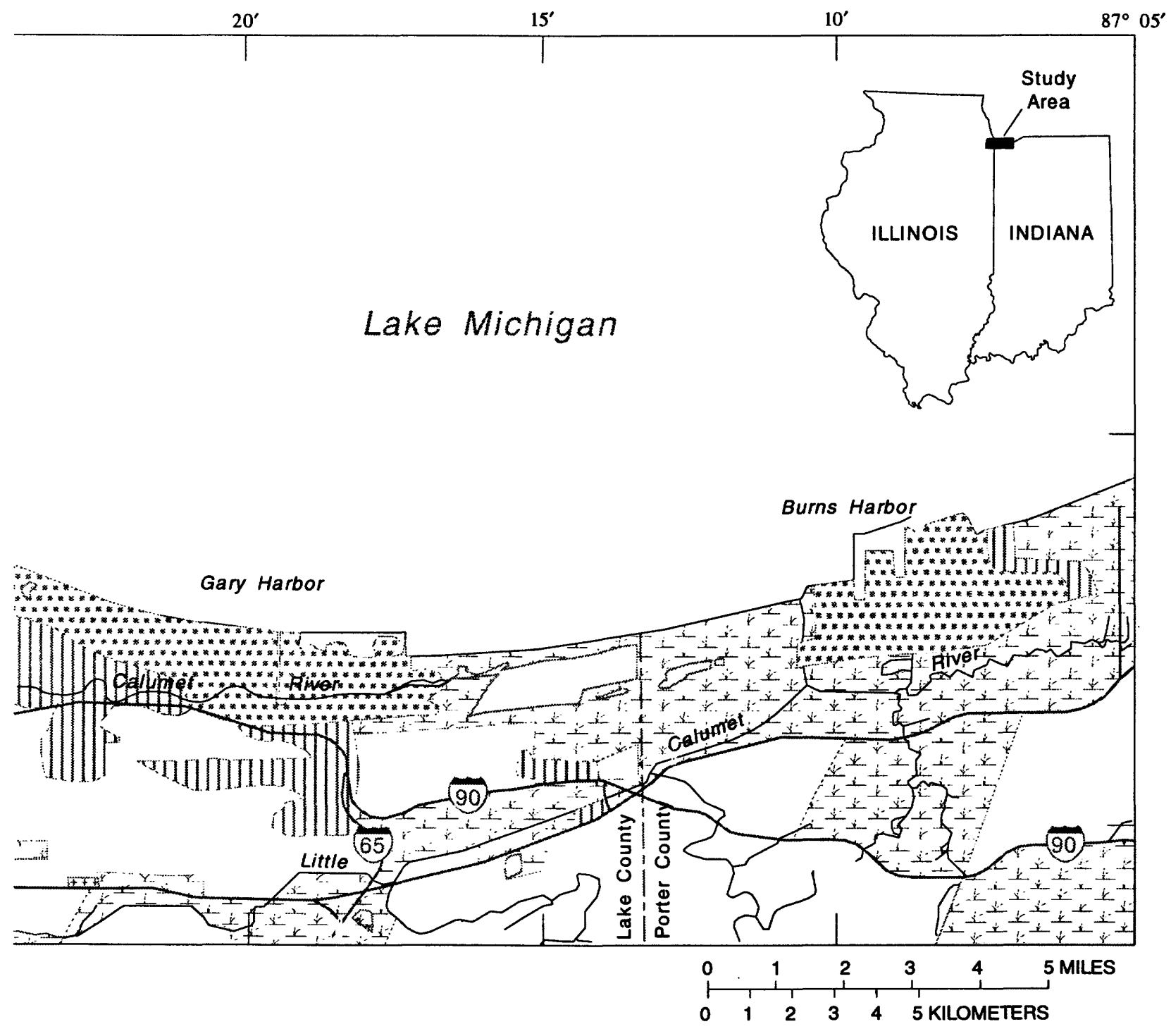

Figure 2. Continued. 


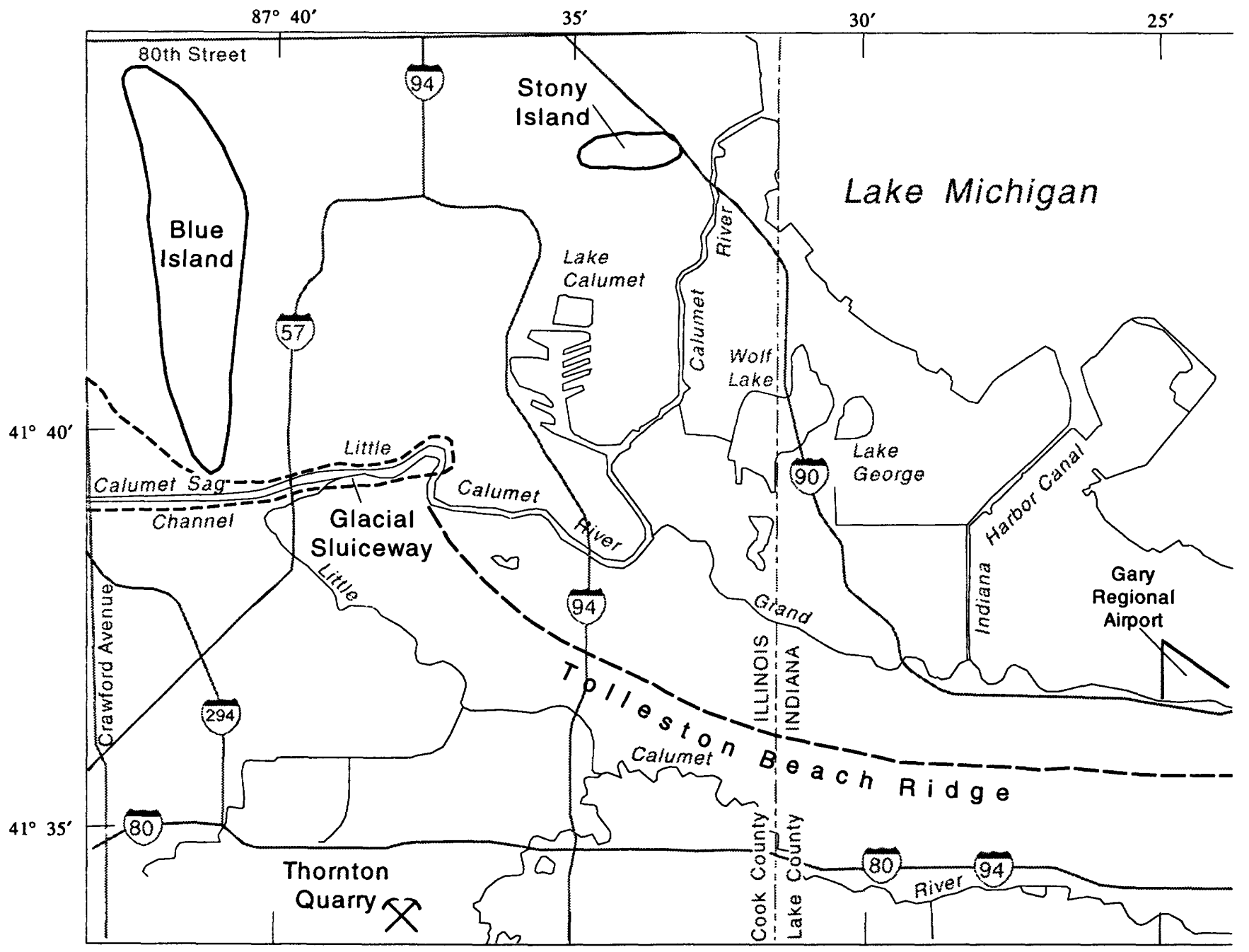

Figure 3. Location of important topographic features, Calumet region of northwestern Indiana and northeastern Illinois (from Kay and others, 1996, fig. 4). 


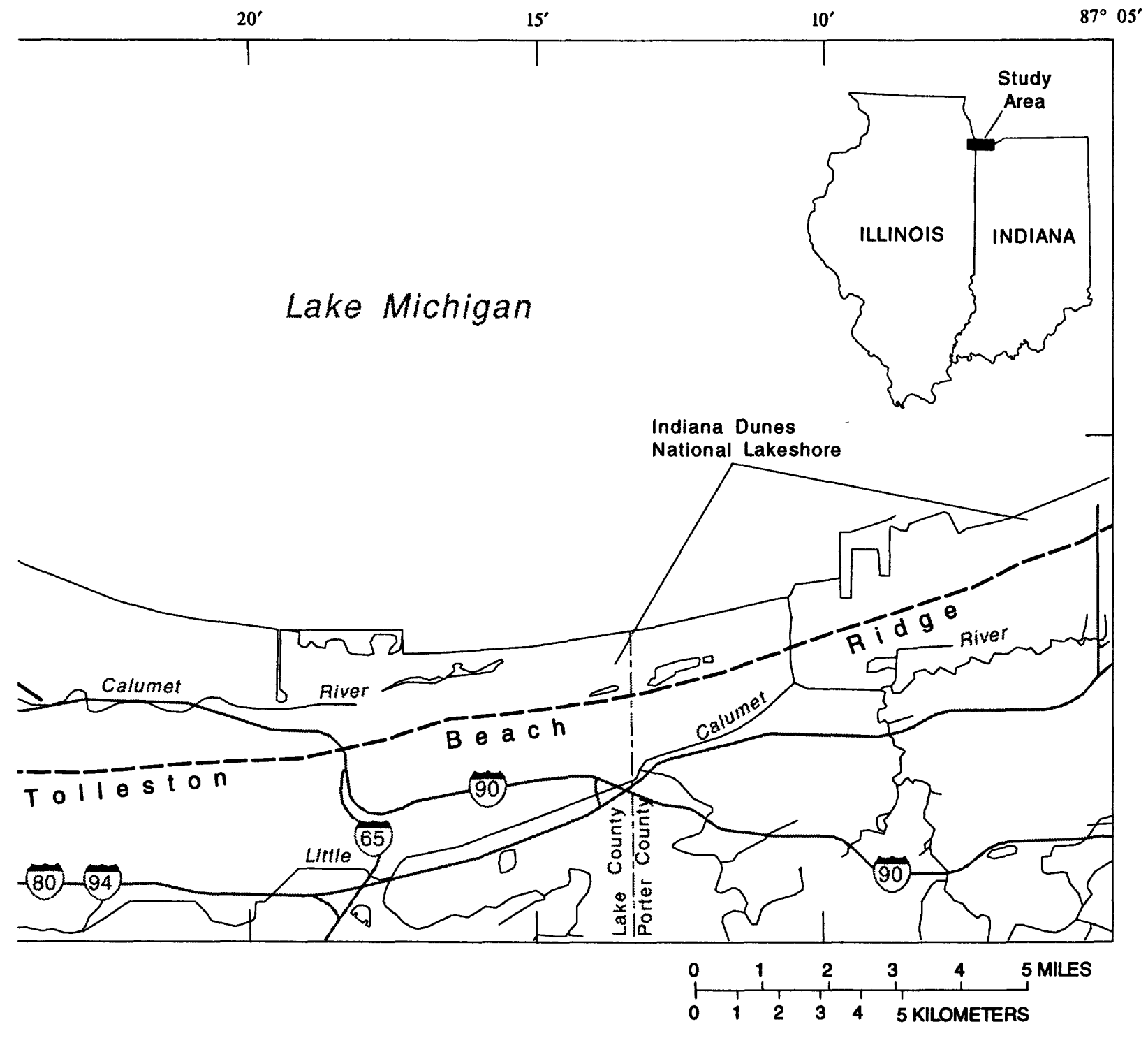

Figure 3. Continued. 


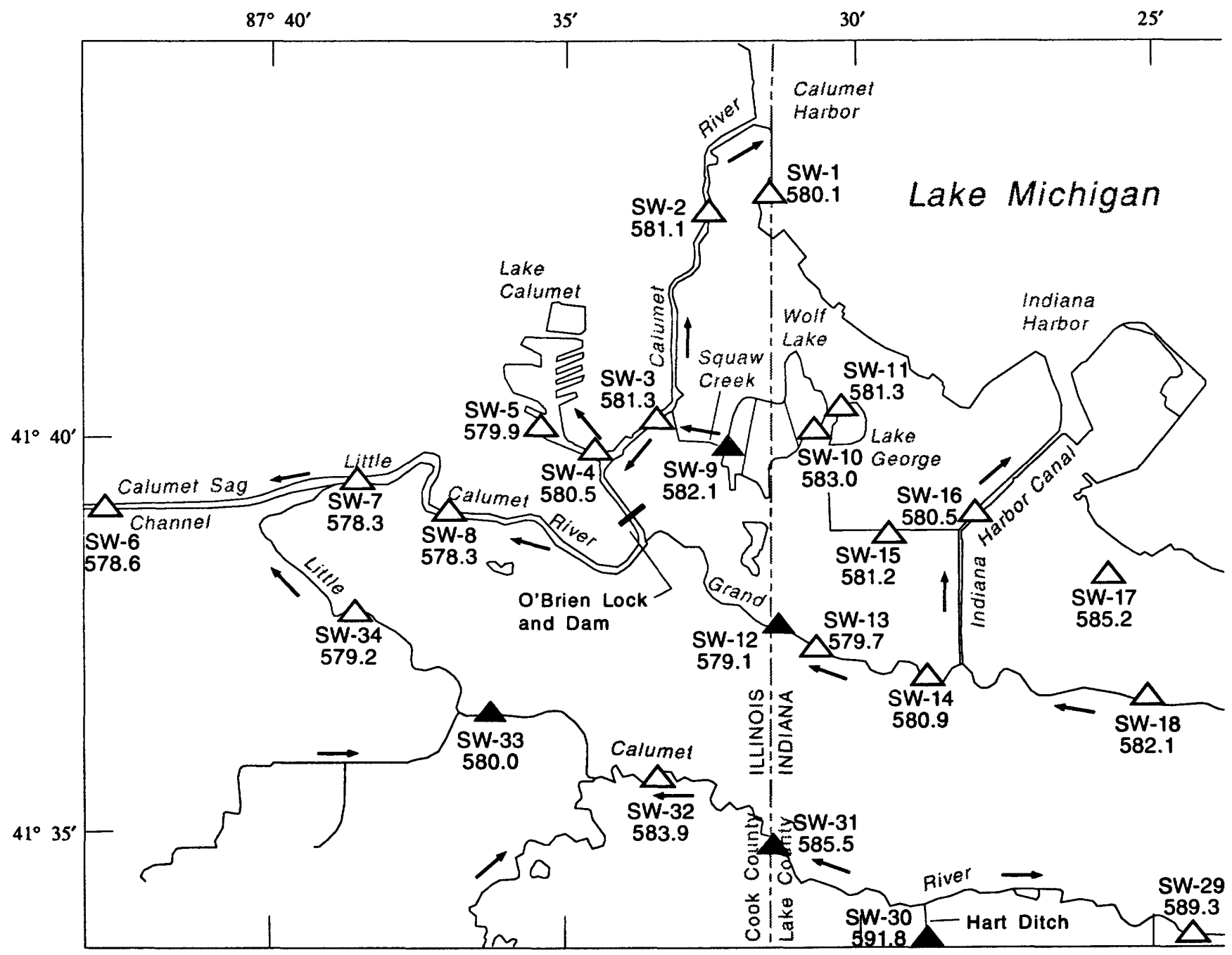

\section{EXPLANATION}

— DIRECTION OF SURFACE-WATER FLOW

SW-15 SURFACE-WATER-LEVEL MEASUREMENT SITE

\$81.2 AND DESIGNATION-Number is water-level

elevation, in feet above sea level

SW-31 CONTINUOUS MONITORING SITE AND DESIGNATION-

$\mathbf{5 8 5 . 5}$ Number is water-level altitude, in feet above sea level

Figure 4. Direction of surface-water flow, Calumet region of northwestern Indiana and northeastem Illinois, June 23-25, 1992 (from Kay and others, 1996, fig. 15). 


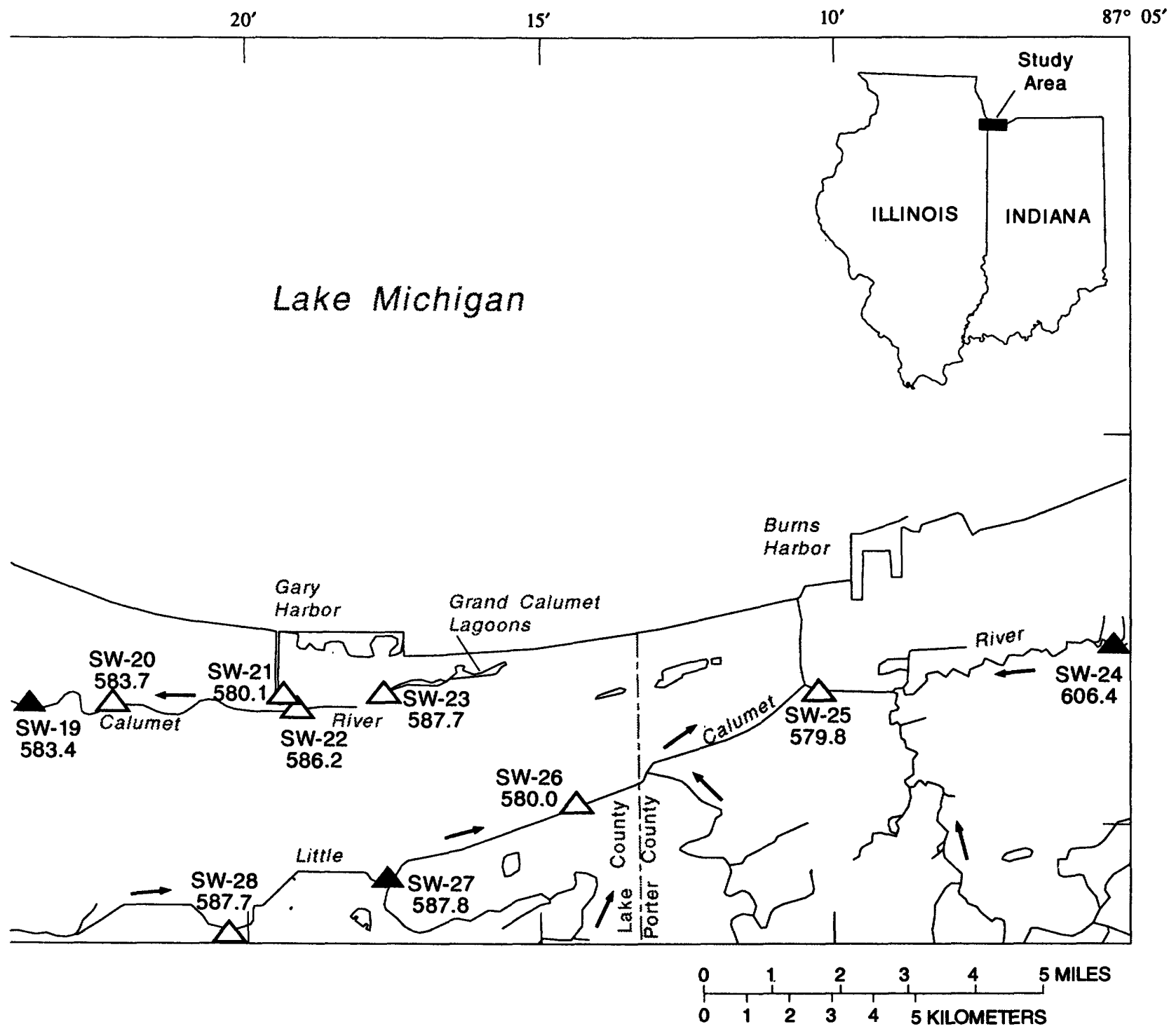

Figure 4. Continued. 


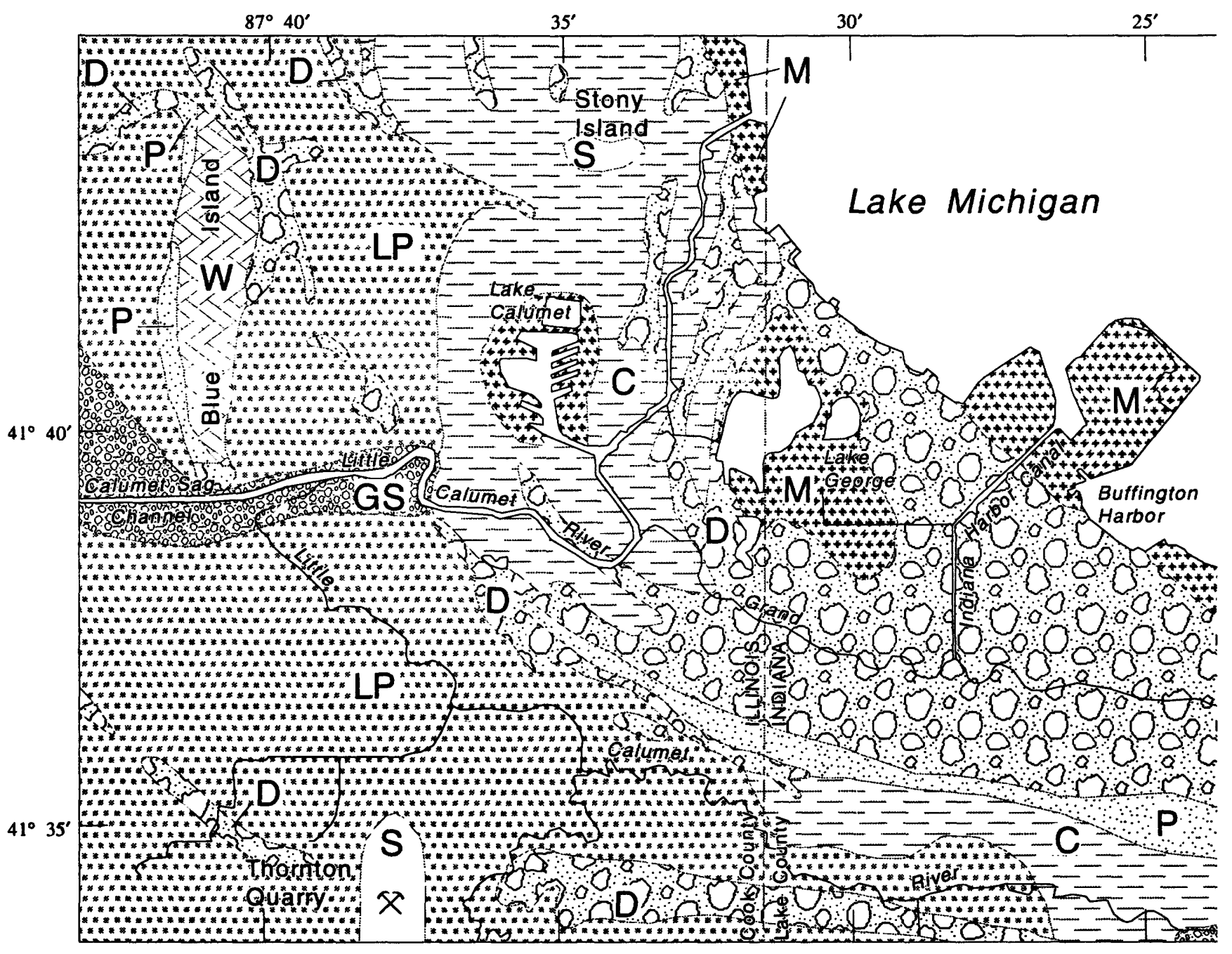

\section{EXPLANATION}

\section{RECENT}

FADE AND MODIFIED LAND-Artificial fill and E.M.t land substantially modified by the removal of unconsolidated deposits. Many small areas not mapped

\section{WISCONSINAN AND RECENT}

Fa: 9 MUCK OR SILT OVER SAND AND GRAVELOutwash sand and gravel overlain in places by thin lacustrine, paludal or alluvial deposits of peat, muck, or clay. Martinsville Formation over outwash facies of Atherton Formation in Indiana, glacial sluiceway in Illinois

$\because P$ SAND AND SOME SILT-Dune deposits. Dune facies of Atherton Formation in Indiana, Parkland Sand in Illinois
SD: SAND AND GAAVEL-Beach and shoreline deposits in bars, spits, and beaches. Some dune sand. Atherton Formation in Indiana, Dolton Member in Illinois

F-C CLAY AND. SILT-Lacustrine deposits. Lacustrine facies of Atherton Formation in Indiana, Carmi Member in Illinois

\section{WISCONSINAN}

TILL-End moraine deposit. Lagro Formation in Indiana, Wadsworth Till in Illinois

\#P: TILL-Wave-scoured lake-bottom till. Lagro Formation in Indiana, Wadsworth Till in Illinois SILURIAN

S DOLOMITE-Marine deposit. Niagaran Series

Figure 5. Surficial geology, Calumet region of northwestern Indiana and northeastem Illinois (modified from Schneider and Keller, 1970; thickness, type, and approximate date of initial fill deposition mapped through 1993 are shown in plates 1-3). 


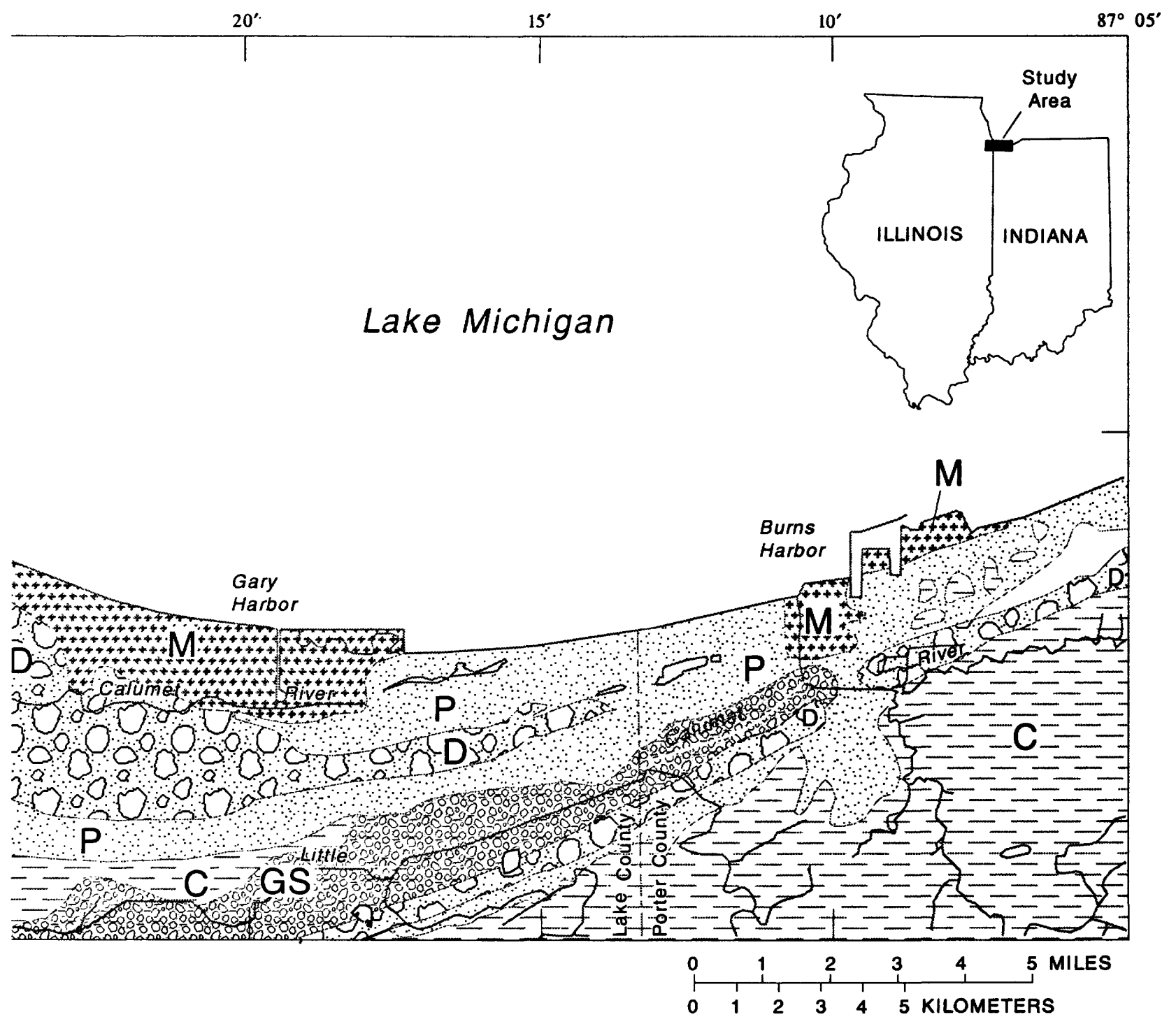

Figure 5. Continued. 
Dolomite bedrock of Silurian age and fill deposits of Recent age are at the surface in some areas.

The surficial sands and permeable fill deposits compose the Calumet aquifer (Hartke and others, 1975 , p. 25). The Calumet aquifer is under water-table conditions and is continuous throughout most of the area east of Lake Calumet but is present only at scattered locations west of Lake Calumet. The extent of the aquifer is approximately defined by the 0 contour on the map of sand thickness (fig. 6). The Calumet aquifer is in good hydraulic connection with surface water except where sheet piles have been driven down into the clay beneath the aquifer (Lee Watson, U.S. Geological Survey, oral commun., 1992). Water in the Calumet aquifer has the potential to discharge to surface water in most of the study area (Kay and others, 1996, p. 45-48).

The unconsolidated till and lacustrine silt and clay deposits, the surficial dolomite deposits, and the low-permeability fill deposits compose the confining unit. Except for small areas northeast of Stony Island and south of Blue Island, the confining unit underlies the Calumet aquifer where the aquifer is present. The water table is in the confining unit in most of the area west of Lake Calumet where the Calumet aquifer is absent (fig. 6). Water in the confining unit has the potential to discharge to surface water in most of the study area where the confining unit is at or near the land surface (Kay and others, 1996, p. 45-48).

The hydraulic properties of the fill deposits are highly variable. Horizontal-hydraulic-conductivity values calculated from slug tests in 46 wells open to fill in Illinois, including 30 wells located at one of the piers in Lake Calumet, varied from $3.7 \times 10^{-4}$ to $3.6 \times 10^{2} \mathrm{ft} / \mathrm{d}$ (Kay and others, 1996, p. 32; Lisa Grassel, Waste Management of North America, Inc., written commun., 1992; McLaren Hart Environmental Engineering Corporation, 1993; George Roadcap, Illinois State Water Survey, oral commun., 1993). These values vary over five orders of magnitude, indicating that the fill deposits are highly heterogeneous.

The heterogeneity of the fill indicates that ground-water flow within these deposits is not uniform, even within an area of a few square feet. Where the fill deposits are predominantly fine grained, unfractured, and relatively well consolidated, groundwater flow is minimal and the fill can be considered part of the confining unit. Where the fill deposits are coarser grained, fractured, or poorly consolidated, higher rates of ground-water flow are possible and the fill can be considered part of the Calumet aquifer. Because highly permeable zones are likely to be present in most of the fill deposits, these deposits, as a whole, are considered part of the Calumet aquifer (Watson and others, 1989, p. 18; Kay and others, 1996, p. 29).

The water-table configuration (fig. 7) is generally a subdued reflection of surface topography. Ground-water flow generally is from areas of high surface topography to areas of low surface topography (Kay and others, 1996, p. 41). Localized changes in this pattern result from installation of sheet piles and slurry walls; enhanced recharge to ground water from landfills and ponded surface water; and ground-water discharge to sewer lines, small ditches, and pumping centers (Cravens and Zahn, 1990, p. 29-30; Watson and others, 1989, p. 30-31; Kay and others, 1996, p. 44). The depth to the water table in the study area is typically less than $15 \mathrm{ft}$.

\section{Development of the Calumet Region}

In 1810, the Little Calumet and Grand Calumet Rivers were two reaches of the same river, referred to as the Grand Konomick River (Moore, 1959, p. 10). At that time, the Grand Konomick River flowed along the approximate path of what is now the Little Calumet River south of the Tolleston Beach Ridge. Flowing from Indiana into Illinois, the river reversed course in a topographic depression between the Tolleston Beach Ridge and the moraine at Blue Island (fig. 3). Flowing eastward into Indiana, the river roughly followed the path of the Grand Calumet River and discharged into Lake Michigan near what are now the Grand Calumet Lagoons (Cook and Jackson, 1978, p. 24).

Sometime between about 1809 and 1820 , a small channel opened between the elbow in the Calumet River south of Lake Calumet and the Grand Konomick River. This created two rivers-the Little Calumet River, which flowed west from Indiana and discharged to Lake Michigan through the Calumet River; and the Grand Calumet River, which continued to flow to the east and discharge to Lake Michigan (Moore, 1959, p. 10). The diversion of water from the Grand Calumet River reduced its current enough that at some time between 1840 and 1845 , beach and dune deposits had blocked the mouth of this channel, preventing flow into Lake Michigan (Moore, 1959, 
p. 11). Under these conditions, the Grand Calumet and Little Calumet Rivers both originated in Indiana and flowed westward into Illinois meeting the newly extended Calumet River and discharging into Lake Michigan (fig. 8). These rivers were surrounded by extensive wetlands.

Lake George, Wolf Lake, Berry Lake, and Long Lake and the surrounding wetlands occupied shallow depressions between the dunes and ridges north of the Grand Calumet River prior to 1840 (U.S. Army Corps of Engineers, 1839) (fig. 8). Sometime between 1872 and 1881, Hyde Lake and Deer Lake were formed (U.S. Congress, 1882, p. 5). The origin of these lakes is uncertain, but the stage of Wolf Lake and Berry Lake may have decreased when channels were dug through the surrounding dunes and beach ridges and water from the lakes drained to the Calumet River. The decrease in lake stage may have resulted in the emergence of previously submerged sand ridges, forming Hyde Lake in what had been the western part of Wolf Lake and Deer Lake in what had been the western part of Berry Lake.

Lake Calumet had a depth of about $10 \mathrm{ft}$ in 1840 (Colten, 1985, p. 14) and was surrounded by wetlands that extended to the Calumet River (fig. 8). The extent of the wetlands was limited by topographic highs associated with Blue Island, Stony Island, and beach ridges near the Calumet River. The size of Lake Calumet varied with the stage of Lake Michigan, but it was typically about $3 \mathrm{mi}$ long and $1.5 \mathrm{mi}$ wide (Colten, 1985, p. 14).

The first steps toward industrial development of the Calumet region began with the laying of railroad track in the mid-1800's. Between 1850 and 1900, at least nine railroad companies had laid tracks through the area to connect Chicago with the eastern seaboard.

Large-scale industrial development of the Calumet region began in 1870 after the U.S. Congress authorized funding to build Calumet Harbor (fig. 1). Water access and rail connections for shipping, abundant water for processing, and proximity to expanding markets in the midwestern and western United States made the Calumet region a desirable location for the manufacture of steel, railroad cars, brick and tile; the mining of sand, gravel, and clay; the processing of petroleum; and meat packaging.

Industrial development spread from Calumet Harbor as access to Lake Michigan was improved. The channel of the Calumet River was straightened in about 1896 and the channel of the Grand Calumet
River was diverted several hundred feet south of its former channel to accommodate industrial development near Gary Harbor in 1906. In addition, the Indiana Harbor Canal was dug in 1906, the Calumet Sag Channel was dug in 1922, and Burns Harbor and Burns Ditch were constructed in about 1926 (Cook and Jackson, 1978, p. 63). During construction of Burns Ditch, the channel of the Little Calumet River was straightened and relocated. Several meanders in the Calumet River also were abandoned when it was straightened to improve its navigability (compare figs. 1 and 8 ).

In addition to altering the rivers, industrialization of the study area and the accompanying waste disposal resulted in the modification or elimination of many of the lakes and wetlands. Hyde Lake, Deer Lake, and Berry Lake had been filled by 1927 to provide land for industrial use. The shorelines of Lake Michigan, Lake Calumet, Wolf Lake, and Lake George have been substantially modified since 1870 because of infilling associated with industrial development and waste disposal (compare figs. 1 and 8 ). Water disposal of solid waste was governed by legislation in Indiana that allowed industries to create land by infilling Lake Michigan. The law, passed as a joint resolution of Indiana Congress in 1906, required permits from Secretary and Chief of Engineers of the Deptment of War. In 1907, state law I.C. 4-18-13, allowed riparian owners "to fill submerged land adjacent to and within the width of their shoreline property." Similar practices were used in Illinois. Fill disposal in Lake Michigan was accomplished by first sinking sheet pilings into the lakebed to form a seawall. The area between the shore and the seawall was then backfilled with lake sand and steel-industry wastes including slag, bricks, ash, casting sand, paper, wood, refractory materials, construction/demolition debris, heavy equipment, empty containers, scrap metal, sludges, and a variety of dusts. By the late 1970's approximately 3,689 acres of Lake Michigan had been filled in the Indiana part of the study area (Indiana Department of Natural Resources, 1979, p. 3). In a large part of the study area, the tops of the sand dunes and beach ridges were scraped off and used to fill adjacent wetlands to make way for residential and industrial development.

Disposal of solid wastes and dredging spoil in lakes and wetlands was deemed desirable for several reasons. Unwanted wastes were disposed of, land that could be used for industrial and urban expansion was 


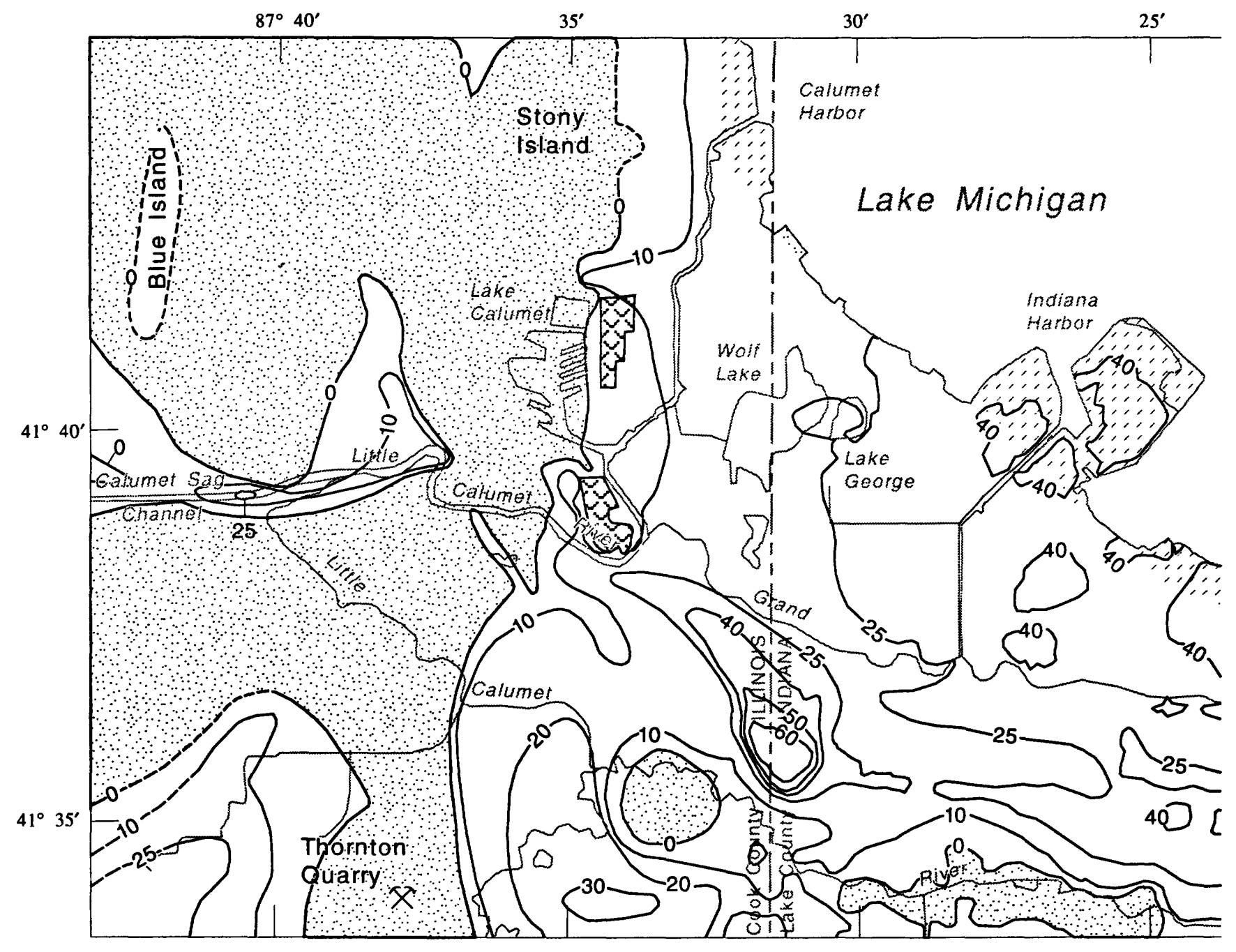

EXPLANATION

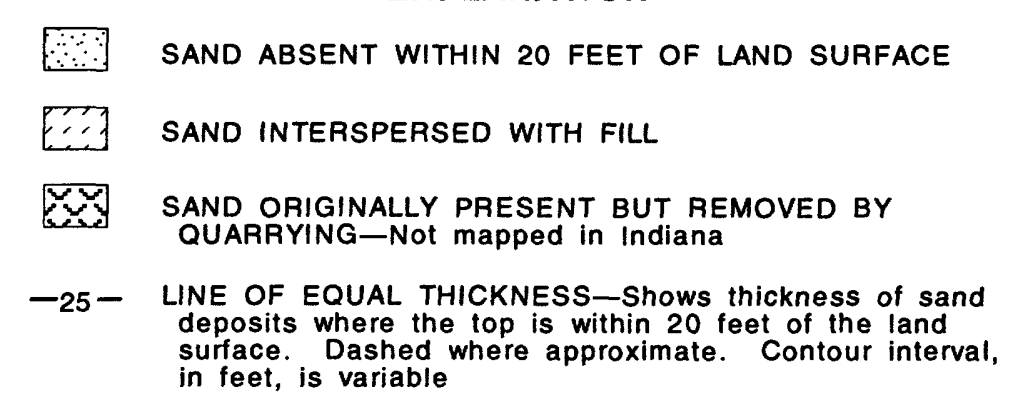

Figure 6. Thickness of sand deposits that compose the Calumet aquifer, Calumet region of northwestern Indiana and northeastern Illinois (from Kay and others, 1996, fig. 8). 


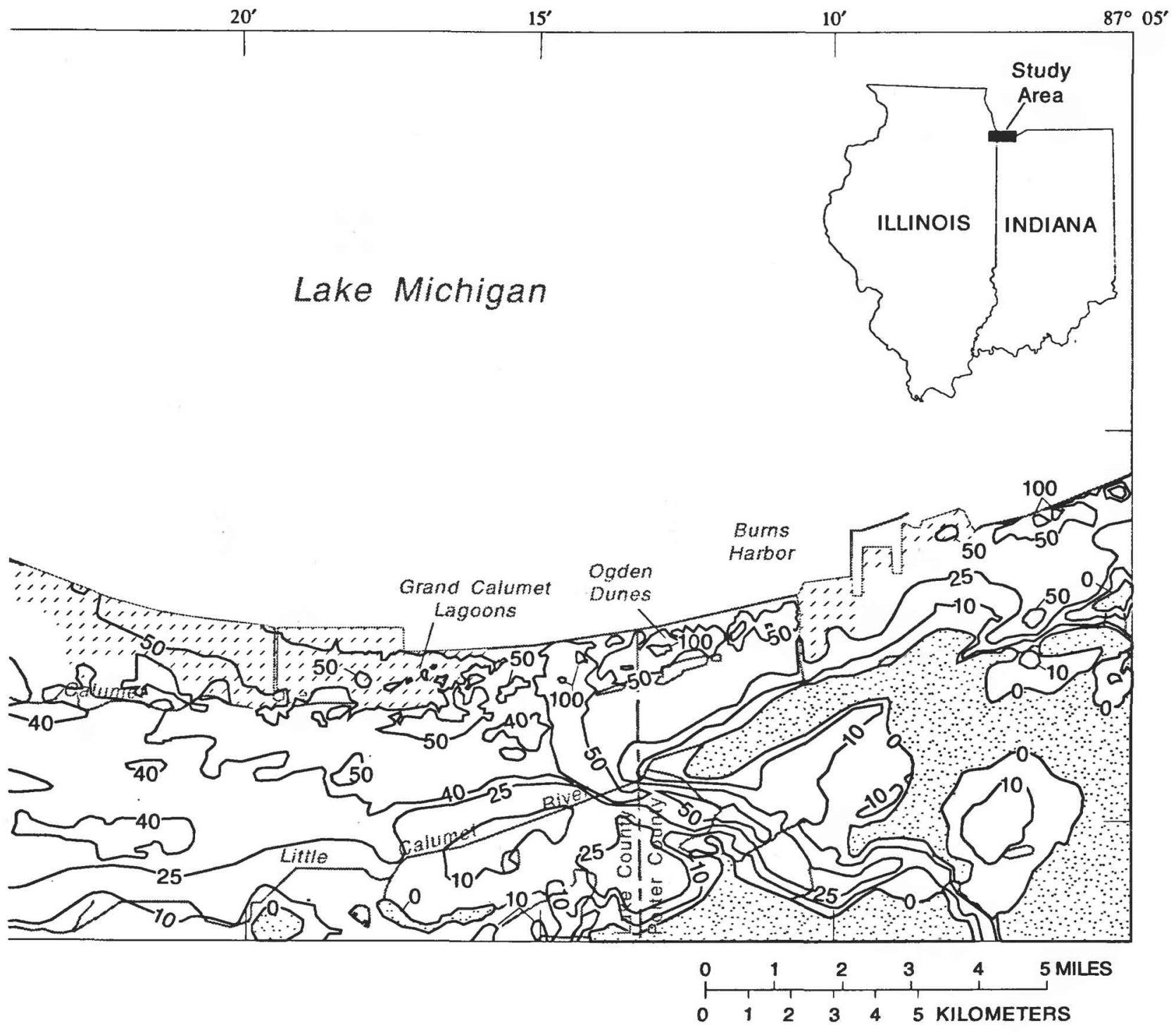

Figure 6. Continued. 


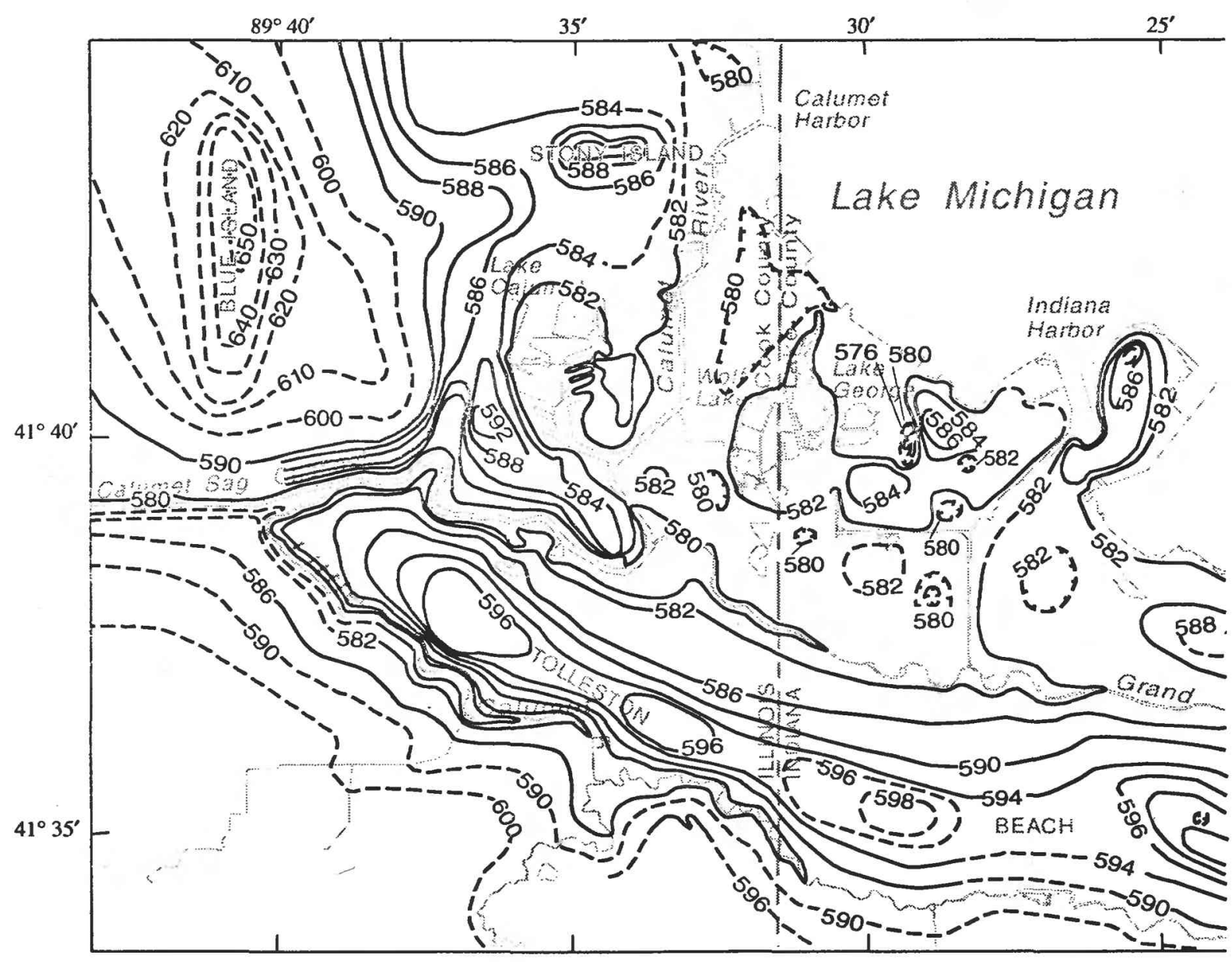

\section{EXPLANATION}

606--. WATER-TABLE CONTOUR--Shows altitude of water table. Dashed where inferred. Contour interval, in feet, is variable. Datum is sea level

Figure 7. Water-table configuration, Calumet region of northwestern Indiana and northeastern Illinois, June 23-25, 1992 (from Kay and others, 1996, pl. 1). 


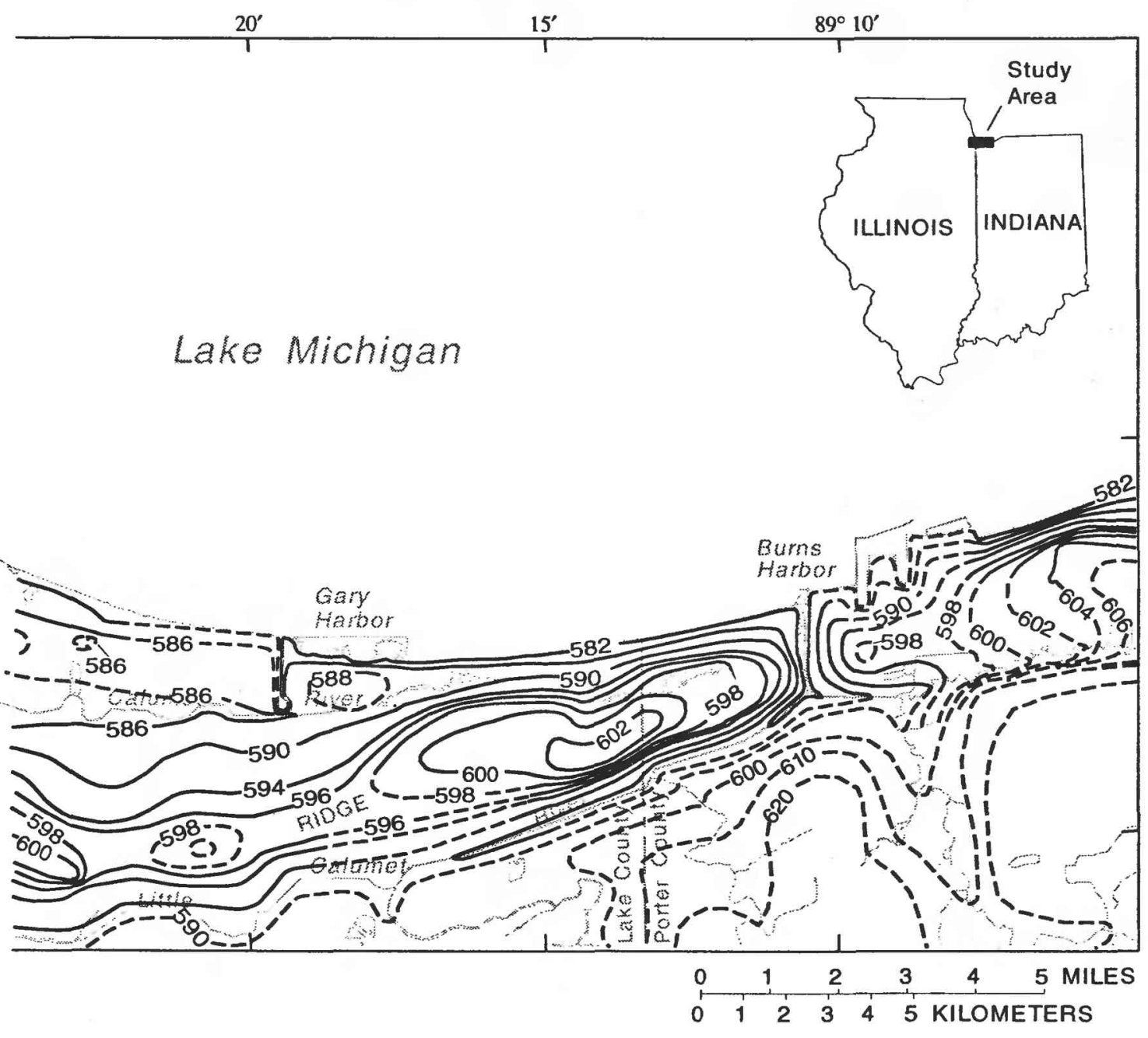

Figure 7. Continued. 


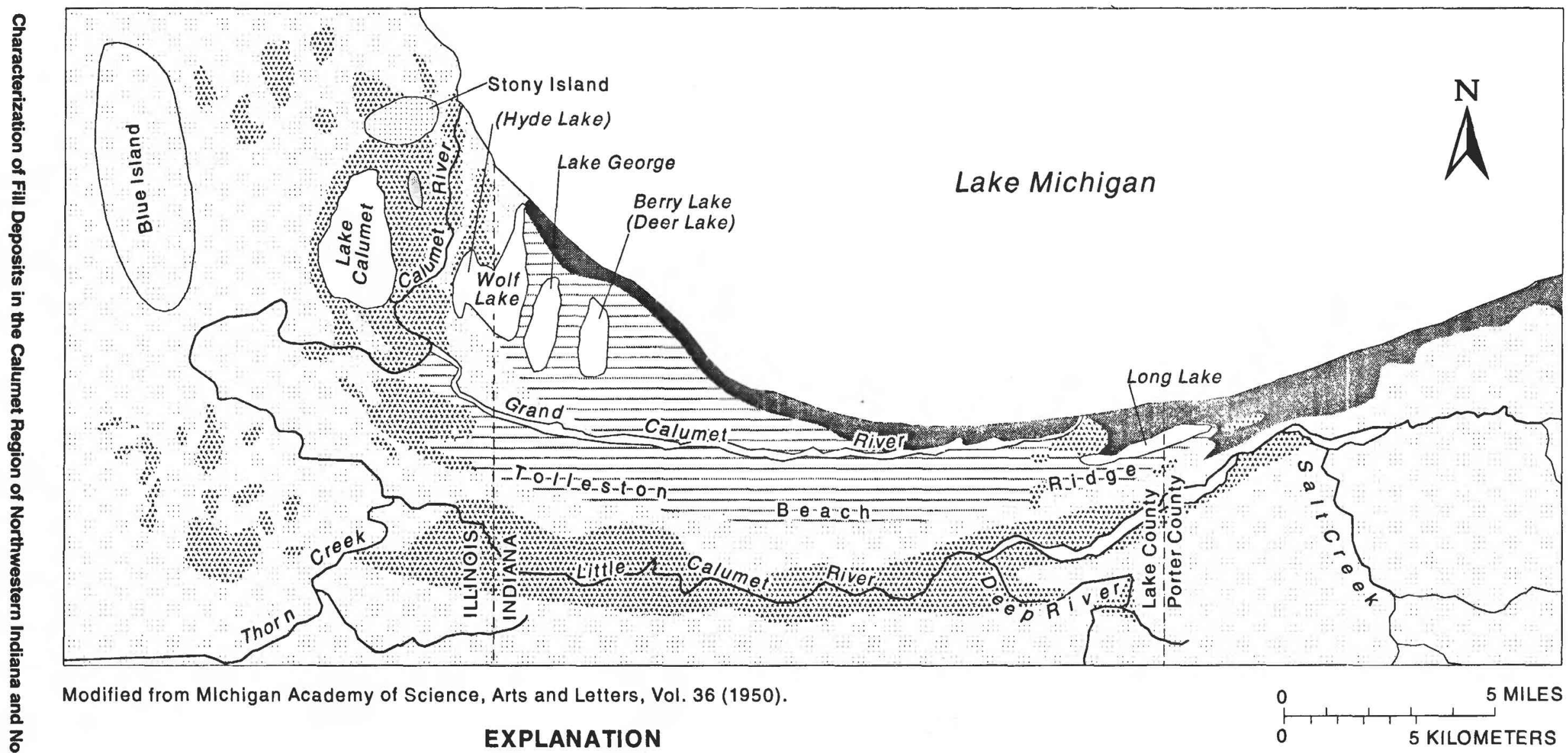

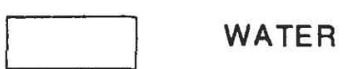

WETLAND

\section{DUNE WITH INTERSPERSED}

WETLAND

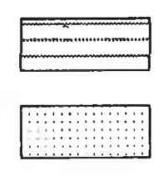

(Hyde Lake) (Deer Lake)
BEACH RIDGES WITH INTERSPERSED WETLAND

DRY LAND--Dunes, beach ridges, morainal islands, bedrock ridge

\section{NAME AND LOCATION OF LAKE THAT} APPEARS AFTER 1840

Figure 8. Physiographic features, surface-water bodies, and selected political boundaries prior to 1840 , Calumet region of northwestern Indiana and northeastern Illinois (modified from Mayer, 1950). 
created, and breeding grounds for mosquitoes and other pests were reduced or eliminated.

\section{Acknowledgments}

The authors extend their thanks to the numerous Federal, State, and municipal agencies and corporations that provided the information and (or) access to the data-collection sites that made this study possible.

American Oil Company (AMOCO), Whiting, Ind.

Bethlehem Steel Company, Burns Harbor, Ind. Bulkmatic Transport, Griffith, Ind.

Canonie, Chesterton, Ind.

Conrail, Chicago, Ill.

Cook County Forest Preserve District

E.I. DuPont DeNemours \& Co., East Chicago, Ind.

Elgin, Joliet, and Eastern Railroad, Joliet, Ill.

Illinois Environmental Protection Agency, Springfield, Ill.

Illinois State Water Survey, Champaign, Ill.

Indiana Department of Environmental Management

Indiana Department of Highways

Indiana Department of Natural Resources, Ground-Water Section

Indiana Geological Survey an Institute of Indiana University

Indiana Toll Road Commission

Inland Steel Company, East Chicago, Ind.

LTV Steel, East Chicago, Ind.

National Steel Corporation, Midwest Steel

Division, Portage, Ind.

Northern Indiana Public Service Company (NIPSCO), Merrillville, Ind.

Ryerson Coil Processing, Chicago, Ill.

U.S. Army Corps of Engineers, Chicago, Ill.

U.S. Army Corps of Engineers, Buffalo, N.Y.

U.S. Steel (USX Corporation), Gary, Ind.

U.S. Steel (USX Corporation), Chicago, Ill.

Waste Management of Illinois, CID Facility,

Calumet City, Ill.

The authors also thank Fred Micke and Carol Witt-Smith of the USEPA, Region 5, Chicago, Illinois, for their assistance throughout this study.

\section{CHARACTERIZATION OF FILL DEPOSITS}

The location, thickness, volume, and type of fill and the approximate date of fill deposition were determined and mapped in the study area. This allowed the types of fill to be related to previously collected ground-water-quality data.

\section{Methods}

Determination of the location, type, and thickness of the fill and the approximate date of fill deposition was accomplished by analysis of topographic maps, maps of surficial geology, aerial photographs, thematic maps of satellite images, results of previous studies of the fill, lithologic logs, field surveys, and the drilling of soil borings. Analysis of this information has allowed the location and thickness of fill (pl. 1), the type of fill (pl. 2), and the approximate date of fill deposition (pl. 3) to be mapped in the study area.

Several maps of all or part of the study area are available depicting conditions prior to 1900 (U.S. Army Corps of Engineers, 1839; Houston, 1872; U.S. Congress, 1882). These maps show the approximate location of the major surface features, including rivers, lakes, wetlands, and roads, but do not include surface topography. The generalized nature of these maps prevents comparison of the exact location of features with subsequent, more accurate maps. However, these maps can be compared with subsequent maps to note gross changes in the surficial features.

The earliest topographic maps were published by the USGS and the U.S. Army Corps of Engineers (USACE) in 1902 at a 1:62,000 scale (Grohmann and Liljenerantz, 1902). These maps cover the entire study area. Topography on these maps was obtained by plane-table survey and triangulation. The next available topographic maps are USGS 7.5-minute quadrangles at a 1:24,000 scale. Topography on the quadrangles was obtained by photogrammetric methods from aerial photographs and plane-table surveys.

Though the dates of the topographic surveys and map publication vary, quadrangles were published for the entire Illinois part of the study area on or about 1901, 1927, 1953, 1964, 1977, and 1992. A quadrangle also was published for the area around 
Lake Calumet in 1960. Quadrangles were published for the Indiana part of the study area on or about 1897 , 1934, 1953, 1968, 1977, and 1991. A USACE map of northern Lake County was published in 1917, and a USGS intermediate map edition was published in 1940 for the eastern part of the study area in Indiana. The dates of the surveys or aerial photographs the maps were based on are similar to the dates of map publication. Changes in surface topography and changes in surficial features (water to land, wetland to dry land) were observed on successive USGS quadrangle maps, allowing the location, thickness, and approximate date of the initiation of fill deposition to be identified.

Maps of surficial geology were published at the $1: 24,000$ scale for the Illinois part of the study area in 1939 (Bretz, 1939). The location of some "made and modified land" is shown on these maps. More recent maps of surficial geology include the entire study area (Schneider and Keller, 1970), the Illinois part of the study area (Willman, 1971, pl. 1), and the Indiana part of the study area (Hartke and others, 1975, pl. 1; Gray, 1989). These maps are at a scale of $1: 250,000$ or $1: 1,000,000$ and show the approximate location of some of the larger, more continuous fill deposits near the large surface-water bodies. The location of the smaller fill deposits and the type, thickness, or age of fill are not identified.

Aerial photographs taken in 1938 and 1990 were analyzed to refine the estimation of the date when fill deposition was initiated as well as interpretations of the location of fill identified by analysis of the topographic and surficial-geologic maps. These photographs also were used to locate fill deposits too small or too thin to be identified on the topographic and surficial-geologic maps. Aerial photos from 1990 did not cover Porter County in Indiana.

Slag deposits were identified and delineated with computer-processed multispectral satellite digital imagery. A 1,300- by 950-pixel subset of two Landsat thematic mapper (TM) images acquired on September 5, 1990, and June 4, 1991, were utilized in the study. These images did not include the eastern quarter of the study area. The TM images consist of 6 spectral bands of 30-meter resolution and 1 spectral band of 120-meter resolution imagery (Lillesand and Kiefer, 1987). Training data for the TM were derived by identifying areas of known surficial slag. These data were digitized into a geographic information system (GIS) vector format and overlaid on the TM coverage. The spectral data corresponding to areas of known slag were used to locate areas with similar spectral signatures. Training data also were developed for land cover without slag. Training signatures were then input to the maximum likelihood classifier. The image classification of maximum likelihood compared to areas of known surficial slag identified with this method are shown in figure 9. Approximately 6,600 acres of surficial slag were delineated using this method. However, surficial-slag deposits covered with substantial amounts of vegetation cannot be detected with this method, so this estimate of slag acreage is conservative.

Areawide studies by previous investigators, especially the U.S. Army Corps of Engineers (1968), Rosenshein (1961), Hartke and others (1975), Indiana Department of Natural Resources (1979), Colten (1985), Environmental Monitoring Systems Laboratory (1991), and Roadcap and Kelly (1994), identified some general areas where fill was emplaced and some of the types of fill in these areas. Some site-specific environmental and geotechnical studies conducted at industrial and waste-disposal facilities in the area have detailed descriptions of the type, thickness, and location of fill and detailed information on the timing of fill operations (for example, Geosciences Research Associates, Inc., 1987; Geosciences Research Associates, Inc., 1988; Warzyn Engineering, Inc., 1987; Ecology and Environment, Inc., 1990; Ecology and Environment, 1993; Eldridge Engineering Associates, 1990; Law Environmental, Inc., 1993). These facilities typically range from about 5 to 300 acres in size. Because they typically involve intensive investigation on a smaller scale, the site-specific studies generally provide detailed information on the fill and can supplement and verify interpretations made from analysis of the maps and aerial photographs.

Lithologic logs from over 1,000 borings drilled for previous environmental and geotechnical studies, and 43 soil borings drilled for this study were used to determine the type, location, and thickness of fill. The spatial distribution of the lithologic information is variable. Most information was obtained for sites where environmental or geotechnical studies were done and is, therefore, concentrated in areas of industry, waste disposal, or interstate highways. Many of the borings done for geotechnical studies, such as for interstate highways, were drilled prior to fill emplacement associated with subsequent construction. In addition, extensive field surveying to verify 


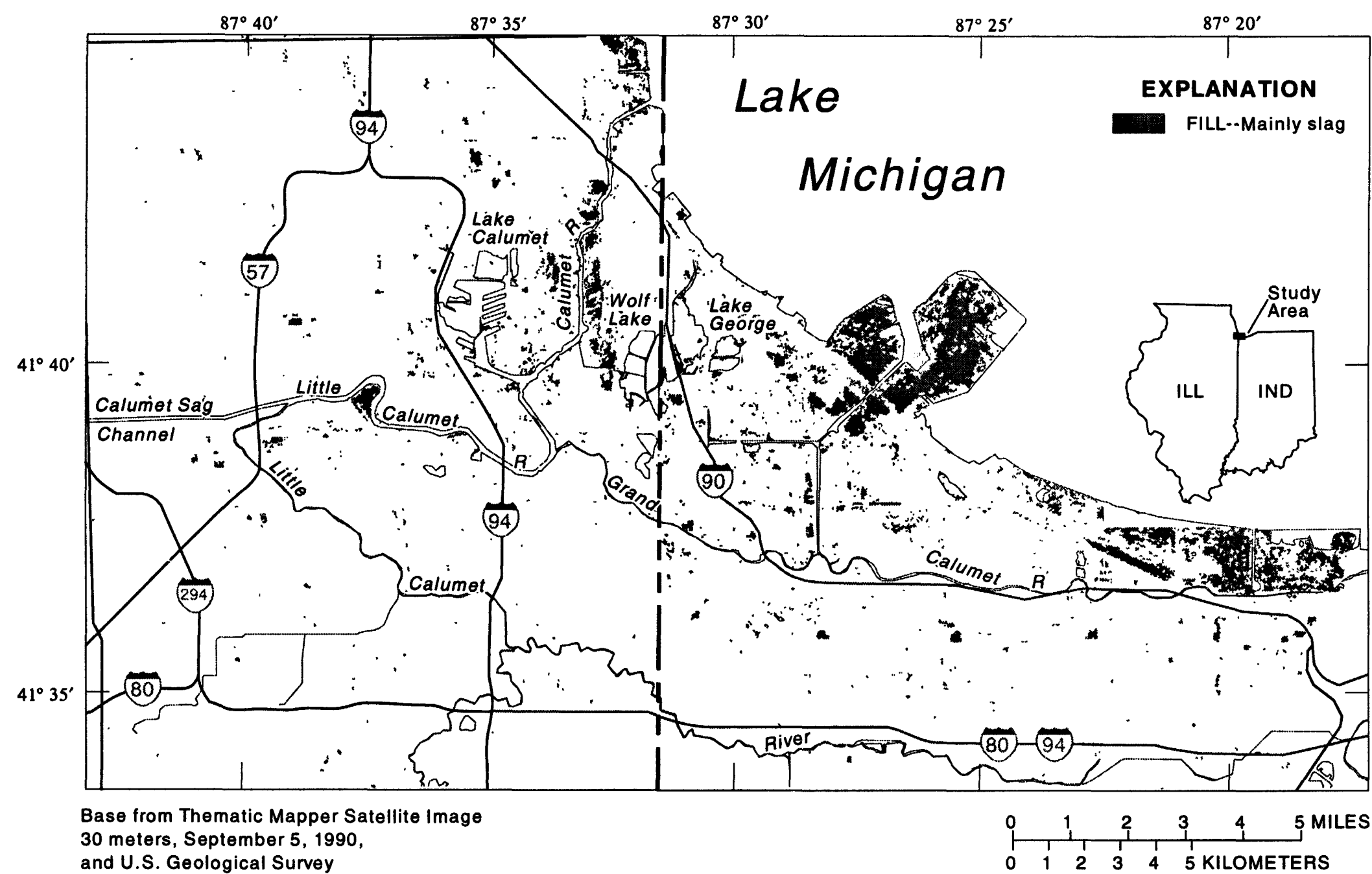

and U.S. Geological Survey

1:24,000 Digital Line Graphs

Albers Equal-Area Conic Projection

Figure 9. Location of areas with similar spectral signatures as areas known to have slag at land surface, Calumet region of northwestern Indiana and northeastern lllinois (eastern part of study area not shown). 
interpretations of the location, type, and thickness of the fill was done by USGS and USEPA personnel as part of this study.

The location and thickness of the fill on plate 1 are based on an analysis of the available data. It should not be inferred, however, that the representation of the fill on plate 1 is exactly correct in every detail.

Because of the inherent heterogeneity of the fill and discontinuous character of many of the fill-placement processes, the type and thickness of the fill materials found at a specific location could differ substantially from the information provided in this report. It also is likely that there are numerous thin, scattered fill deposits in this area that have not been identified.

The location and thickness of fill depicted on plate 1 do not include fill deposits that may be present below the water level of the lakes. Most of the fill areas along Lake Michigan are bounded by sheet piling and typically do not extend below water out into the lake. It is probable, however, that fill extends below the water surface in most of the lakes surrounded by fill. This includes Wolf Lake, Lake Calumet, Lake George, and an unnamed lake located about $1 \mathrm{mi}$ south of the confluence of the Calumet Sag Channel and the Little Calumet River (pl. 1).

Analysis of the data indicates that most of the fill is a heterogeneous mixture of steel-industry wastes, municipal solid waste, dredging spoil, construction debris, ash and cinders, and natural material. Fill deposits composed of industrial wastes also were detected. For the purposes of this report, industrial wastes and steel-industry wastes are considered separate materials. Steel-industry wastes are considered to be primarily solid materials such as slag, casting brick, and foundry sand. Industrial wastes, which may be produced by the steel industry, can include liquids and sludges that contain material such as oils, paint, tar, solvents, and grease. Wood chips used for purification of coal gas also are considered industrial wastes in this report. The heterogeneity of the fill complicates the determination of a particular fill type and identification of its spatial extent at many locations. With the exception of industrial waste, which was mapped wherever substantial quantities were documented, if more than one type of fill was described at a given location, the predominant fill type identified was mapped on plate 2 .

The types of fill are categorized as follows:

1. Industrial waste

2. Municipal solid waste
3. Steel-industry wastes (primarily slag)

4. Dredging spoil

5. Biological sludge

6. Ash and cinders

7. Construction debris

8. Natural material

The date of the initiation of fill deposition in the study area was divided into six periods: pre-1902, 1902-27, 1928-53, 1954-64, 1965-77, and 1978-93

(pl. 3). Areas of fill that first appear on maps from 1897 and 1901 were mapped as emplaced before 1902. Areas of fill that first appear on maps published on or about 1917,1927 , or 1934 were mapped as emplaced from 1902 to 1927 . Areas of fill that first appear on maps published on or about 1940 or 1953 were mapped as emplaced from 1928 to 1953 . Areas of fill that first appear on maps published on or about 1960,1964 , or 1968 were mapped as emplaced from 1954 to 1964. Areas of fill that first appear on maps published on or about 1977 were mapped as emplaced from 1965 to 1977 . Any areas of fill that first appear on maps published after 1980 were mapped as emplaced from 1978 to 1993 . Because many of the maps have different dates of survey and publication, the dates for the time of fill emplacement must be considered as approximate.

Fill has been removed in some places (for example, a large area of fill southwest of Lake Calumet was excavated at some time between 1978 and 1990). Therefore, the historical extent of fill shown on plates 2 and 3 differs in some areas from the current extent of fill shown on plate 1 . Only the initial date of fill deposition at a given location is shown on plate 3. No information about when deposition ceased or about the dates of fill deposition subsequent to the initial emplacement is provided. There are many areas where fill was deposited at the same location at different times. The type of fill deposited at a given location may have changed through time.

Volume calculations for the fill materials were obtained using a GIS. Digital map layers (coverages) were generated for the type, age, and thickness of fill in the study area. These coverages contain polygons attributed with location and thickness, age, and type of fill present. The thickness and type coverages can be joined using an overlay operation. This operation allows polygons to be selected based on single or multiple attributes. After the overlay operation, the selection for all slag polygons automatically allows access to the thickness values. In addition, the area 
value for each polygon given in user-defined units is automatically calculated with the GIS. Total volume is calculated by multiplying the thickness value by the area value.

\section{Location and Thickness}

Fill deposits are almost continuous along the shore of Lake Michigan, especially in the western two-thirds of the study area (pl. 1). Fill was placed into Lake Michigan primarily to create land for industrial expansion at the steel mills near Calumet Harbor, Indiana Harbor, Gary Harbor, and Burns Harbor (compare fig. 2 and pl. 1). The fill in Lake Michigan typically is between approximately 20 and $60 \mathrm{ft}$ thick but can be almost $80 \mathrm{ft}$ thick in some places. Fill thickness generally increases lakeward.

Fill deposits also are nearly continuous from the area approximately defined by the western edge of the Calumet Sewage Treatment Plant, the southern bank of the Little Calumet and Grand Calumet Rivers, the southern edge of Stony Island, and the area immediately east of the Indiana Harbor Canal (pl. 1). These deposits merge with the fill along Lake Michigan east of the canal.

Much of the fill between Lake Calumet and the area east of the Indiana Harbor Canal resulted from the infilling of surface-water bodies or the leveling of the land surface. Hyde Lake, Deer Lake, and Berry Lake (fig. 8) have been completely filled to create land for steel manufacturing, petroleum refining, and storage. The southern part of Lake George, the northern and southeastern parts of Wolf Lake, abandoned meanders in the Grand Calumet and Calumet Rivers, and about half of Lake Calumet also have been filled (compare fig. 8 and pl. 1). The thickness of the deposits between Lake Calumet and the Indiana Harbor Canal is highly variable, ranging from about $1 \mathrm{ft}$ in much of the area to over $100 \mathrm{ft}$ at some of the landfills near Lake Calumet.

Fill deposits also are present along the banks of the Little Calumet River and the Calumet Sag Channel west of the Calumet Sewage Treatment Plant. The material near the Little Calumet River appears to have been deposited to raise the land surface a safe distance above the river for residential and industrial use, to dispose of dredgings and solid wastes from steel manufacturing, and as foundation for highways and railroads. These deposits are typically less than $20 \mathrm{ft}$ thick. Fill used for road construction and to create level land for a petroleum refinery (fig. 2) also is located near the channel. These deposits typically are less than $5 \mathrm{ft}$ thick.

Fill used for railroad and highway foundations is located throughout the study area (pl. 1). These foundations were often placed on top of, or next to, pre-existing fill. The roadbed deposits are long, narrow, and generally less than $20 \mathrm{ft}$ thick. Fill also was used to raise street levels northeast of Stony Island above the surrounding wetlands, forming a rectangular pattern as shown on plate 1 . These deposits are always less than $10 \mathrm{ft}$ thick and are typically less than $5 \mathrm{ft}$ thick.

Isolated fill deposits, typically between approximately 20 and $40 \mathrm{ft}$ thick, were identified along the eastern and western flanks of Blue Island about $1 \mathrm{mi}$ north of the Calumet Sag Channel, about 1 mi south of the confluence of the Little Calumet River and the Calumet Sag Channel, about 0.25 mi north of Interstate 80/94 west of the State line, along the northern edge of Interstate 80/94 in Gary, west of Gary Regional Airport, and near the Gary-Hammond boundary about $0.75 \mathrm{mi}$ north of Interstate 80/94 (compare fig. 1 and pl. 1). Most of these sites were once sand or clay quarries.

Isolated areas of fill less than $10 \mathrm{ft}$ thick are scattered throughout the study area. These deposits are too numerous to describe individually but were typically identified from lithologic logs in residential areas. The extent of the fill at these sites cannot be readily identified. It is likely, however, that these small, thin deposits are widespread in residential areas.

Analysis of the extent of fill mapped on plate 1 indicates fill covers about $60.2 \mathrm{mi}^{2}$ of the study area. When the area of fill mapped on plate 1 is multiplied by the average thickness of the waste, a volume of about $2.1 \times 10^{10} \mathrm{ft}^{3}$ of fill is calculated to be present.

\section{Type}

Industrial wastes are, or at one time were, present in the fill at numerous locations around Lake Calumet (Ecology and Environment, Inc., 1980; STS Consultants, Ltd., 1982; STS Consultants, Ltd., 1983; Weston-SPER, 1983; Integrated Site, Inc., 1990; Black and Veetch, 1993; Bar Engineering, 1995; Carlson Environmental, Inc., 1995), and between the Indiana Harbor Canal and Gary Harbor 
(Environmental Monitoring Systems Laboratory, 1991). Industrial wastes also are present in the fill at one site east of Gary Harbor (Geraghty and Miller, Inc., 1995), one site near the Calumet River (Hanson Engineers, 1990), one site near the State line south of Wolf Lake (STS Consultants, Ltd., 1980), and at two sites near Burns Harbor (Baker/TSA, Inc., 1988) (pl. 2). Some of this fill has been removed or surrounded by low-permeability materials designed to isolate the fill from the environment in the years since it was originally emplaced.

Many of the municipal solid wastes described in lithologic logs are materials that are resistant to chemical and biological degradation (glass, plastics). Most of the organic waste (food, grass cuttings) has already been degraded to the point where it is described as soil or ignored in lithologic descriptions. It also was common practice to burn municipal solid waste, leaving only glass, ash and cinders. This makes identification of areas of municipal solid-waste disposal difficult if site documents do not describe the wastes deposited. It is possible that there are areas of municipal solid-waste disposal in the study area that have not been identified on plate 2 . This includes a small area of the Calumet Sewage Treatment Plant near Interstate 94 , where municipal solid wastes may have been disposed of prior to expansion of plant operations into the fill area. Municipal solid wastes may have also been deposited in parts of the area east of the State line north of Wolf Lake.

Municipal solid wastes are concentrated in random dumps and sanitary landfills near Lake Calumet and in sanitary landfills along Blue Island, about $1 \mathrm{mi}$ south of the confluence of the Little Calumet River and the Calumet Sag Channel, about $1 \mathrm{mi}$ west of the State line near Interstate 80/94 in Illinois, and in several locations between the Little Calumet and Grand Calumet Rivers in Indiana (pl. 2). Lithologic logs and site documents indicate that other materials, including oily wastes and inking wastes, were disposed of with the municipal solid wastes in Illinois (Warzyn Engineering Inc., 1991, table 8a). It is probable that other materials were disposed of with municipal solid wastes in Indiana.

Steel-industry waste is the most widespread fill type in the study area (pl. 2). The extent of the steelindustry wastes mapped on plate 2 indicates that steelindustry wastes cover about $30.6 \mathrm{mi}^{2}$ of the study area. If the area of steel-industry waste mapped on plate 2 is multiplied by the average thickness of the fill mapped on plate 1 , a volume of about $1.3 \times 10^{10} \mathrm{ft}^{3}$ of this fill material is present in the Calumet region. These wastes consist mainly of slag, but foundry sand and casting bricks also have been used as fill. Slag, a byproduct of the reduction of iron ore to iron and iron to steel, has been the principal fill material in the Calumet region since the early 1900's. Over 500 tons of slag can be produced by a single blast furnace daily (Dull and others, 1958, p. 510) and about 4 million tons of slag were produced in Lake and Porter Counties alone in 1970, a year of above average steel production (Brown, 1972, p. 260). Steel-industry wastes compose virtually all of the fill along Lake Michigan in the western two-thirds of the study area, and most of the fill around the Indiana Harbor Canal, Wolf Lake, Lake George, the western shore of Lake Calumet, and at the steel mills along the Calumet and Little Calumet Rivers (compare fig. 2 and pl. 2). Slag also has been used as foundation for streets, bridges, highways, and railroads throughout the area.

Dredging spoil is primarily sand- and silt-sized sediment, which can contain liquid and solid material from urban runoff, industrial and municipal discharges, and sewer overflows. Because it is composed primarily of sand and silt, dredging spoil can easily be misidentified on lithologic logs. Therefore, some areas where lithologic logs do not describe fill are mapped as dredging spoil on plate 2 if other information indicates its presence.

Dredging spoil is typically located in small, thin strips along the banks of the Indiana Harbor Canal, Burns Ditch, the Calumet Sag Channel, and the Calumet and Little Calumet Rivers. Sediments that have filled in the abandoned river channels also are considered dredging spoil for the purposes of this report. At some locations along the Calumet and Little Calumet Rivers, spoil piled along riverbanks was removed and placed in centralized disposal sites east of Lake Calumet (including some of the landfills); near the confluence of the Calumet, Little Calumet, and Grand Calumet Rivers; and about $1 \mathrm{mi}$ south of the confluence of the Little Calumet River and the Calumet Sag Channel. Steel-industry waste and municipal solid waste also were placed at some of the landfills east of Lake Calumet.

Dredging spoil from the Calumet River and rivers outside of the study area also is present at a disposal facility at Calumet Harbor south of the mouth of the Calumet River (pl. 2). The interior perimeter of this facility is surrounded by fine-grained dredge 
spoils that limit the hydraulic connection between the interior of the facility and the environment. Wastes, which were present on the lakebed at the northern part of the facility before it was constructed, were dredged during construction and interned in the southern part of the facility (Joseph Jacobazzi, U.S. Army Corps of Engineers, written commun., 1994).

Biological sludges, primarily sanitary sewage, are currently placed in paved bituminous drying cells at the Calumet Sewage Treatment Plant and immediately north of the junction of the Calumet River and Lake Calumet. These sludges are biologically treated and dewatered before removal and disposal at a sanitary landfill. Because these sludges are contained by a liner and are frequently removed from the treatment areas, they are not considered fill until deposited in a landfill, even though the treatment areas are shown on plate 2 .

Large volumes of ash and cinders were produced from wood and coal burning in homes, train engines, and industries since the 1870's. Large deposits of ash and cinders are present north of Lake George, east of the Indiana Harbor Canal, between Lake Calumet and Stony Island, along several of the railroad lines, and west of Wolf Lake. The deposits west of Wolf Lake are composed primarily of flue dust from steel manufacture. Deposits near the railroad lines were typically laid for roadbed or were refuse from the engines. Smaller deposits of ash and cinders are scattered throughout the region.

Construction debris consists of concrete, wood, and brick produced from the demolition of buildings and roads. Most of the construction debris used as fill in this area was deposited near Lake Calumet and along the Grand Calumet River in the vicinity of the State line. Construction debris also has been used as roadbed for railroad lines.

Natural material is composed of sand, silt, and clay commonly derived from building excavations or the leveling of the land surface for construction. For example, the dune and swale topography that formerly covered most of the area adjacent to the Indiana Harbor Canal was eliminated by leveling the dunes and using the sand to fill in the intervening wetland swales, allowing residential and industrial construction in this area. Natural materials also are used as foundation for streets, railroads, and highways. Natural material also was used to create land for industrial use in Lake Michigan near Burns Harbor.

\section{Date of Deposition}

The earliest period of fill deposition identified for this report occurred between 1840, the approximate beginning of industrial and residential development of the study area, and about 1902, when the first reliable topographic maps were published. Large-scale fill deposition in this area began with the onset of industrialization in about 1870. Much of the fill deposited before 1902 was used as foundation for the streets north and east of Stony Island and the railroad tracks in the area. In 1880, construction of the Pullman area was initiated by placement of about $5 \mathrm{ft}$ of fill along the western shore of Lake Calumet. Fill also was emplaced along the Lake Michigan shoreline north of Calumet Harbor, and along much of the Calumet River. Hyde Lake was almost completely filled by 1902. Small amounts of fill also were deposited south of Stony Island during this time. Much of the Indiana part of the study area was sparsely inhabited prior to 1902, but some fill was deposited north of Lake George and in Deer and Berry Lakes. Fill deposition in the vicinity of Deer and Berry Lakes began in 1889 to create land for a petroleum refinery.

Between 1902 and 1927, large amounts of fill were deposited as industrial activity within the study area accelerated. This period marks the beginning of the use of fill to create land from Lake Michigan between Gary Harbor and Indiana Harbor and the continuation of infilling of Lake Michigan near Calumet Harbor. Fill also was placed near the areas where steel is (was) manufactured along the Calumet and Little Calumet Rivers (compare fig. 2 and pl. 3). Several rail lines were expanded and new ones were built, requiring fill for roadbed. Dredging spoil was piled along the banks of the Calumet Sag Channel, the Indiana Harbor Canal, and the Calumet and Grand Calumet Rivers as their channels were dug, straightened, and dredged. The western half of Lake Calumet continued to be infilled between 1902 and 1927. Several areas between Lake Calumet and Stony Island, north of Lake George, and near the Indiana Harbor Canal also were sites of fill deposition.

There was a large increase in the area used for fill deposition between 1928 and 1953. The steel industry continued to expand the area used for fill around Lake Michigan, the Little Calumet River, Wolf Lake, Lake George, and the east bank of the Calumet River. Infilling of Lake Calumet continued with the establishment of a solid-waste landfill along the 
northern shore by the city of Chicago in 1940. Fill deposition around the Indiana Harbor Canal also continued as the land surface was raised and the wetlands were filled. Fill was deposited as roadbed by 1953 for what are now Interstates 80 and 94 in the Illinois part of the study area. These interstate highways extend along the western edge of Lake Calumet and the southern boundary of the study area. Fill deposition began in the wetlands east of Lake Calumet, in the wetlands and abandoned meanders in the Calumet and Grand Calumet Rivers, near the Calumet Sewage Treatment Plant, and in several shallow excavations around the Calumet Sag Channel. Fill deposition continued near industrial facilities along the southwestern corner of Lake Calumet. Much of the area along the Little Calumet River between the Calumet Sag Channel and the Grand Calumet River was used for fill deposition during at least part of this period.

Except for the new fill area associated with construction of the steel mills at Burns Harbor, infilling at a former clay pit about $1 \mathrm{mi}$ south of the confluence of the Calumet Sag Channel and the Little Calumet River, and the beginning of landfill operations at former clay pits along the eastern part of Blue Island, land used for fill deposition between 1954 and 1964 expanded from most of the areas where fill was deposited before 1954. Fill deposition continued to expand into Lake Michigan in Indiana, the wetlands east of Lake Calumet, the Calumet River near the O'Brien Lock and Dam (fig. 4), the Calumet Sewage Treatment Plant, and west of the steel-manufacturing facility in the bend of the Little Calumet River southwest of the Calumet Sewage Treatment Plant

(fig. 2). Large parts of the southwestern corner of Lake Calumet also were infilled during this time. Roadbed for Interstates 57, 90, 94, and 294 and foundation for an industrial facility north of Lake Calumet also were laid down during this period, generally on top of preexisting fill. Small amounts of fill were dumped in an abandoned dock on the Calumet River, along much of the shore of the Grand Calumet River west of Indiana Harbor, and at the northern tip of what was once Hyde Lake. This period also marked the beginning of disposal of fill at the location of the current sanitary landfills south of Lake Calumet.

In comparison to previous periods, fairly small amounts of new land were used for fill deposition between 1965 and 1977. Filling of Lake Michigan continued at sites near Indiana Harbor, east of Gary
Harbor, and at Burns Harbor. Fill used for roadbed was emplaced when new roads were built leading to the steel mills near Burns Harbor. Filling of Lake Calumet continued as piers and causeways were built. Sanitary landfilling operations began at the site of former clay pits along the western part of Blue Island, south of the Little Calumet River west of Interstate 94, and at several sites in Indiana in the early 1970's. Sanitary landfilling operations also began in the vicinity of former dump sites along the eastern shore of Lake Calumet in the early 1970's. Sanitary landfilling operations along the north shore of Lake Calumet continued to expand during this time. Operations at those sanitary landfills, which were not former clay pits, typically involved excavation to a depth of about $30 \mathrm{ft}$ below land surface. In addition to the removal of the in-situ geologic material, this usually required removal of the previously deposited fill. In addition to sanitary landfilling of municipal wastes, disposal of dredging spoil in settling ponds southwest of the O'Brien Lock and Dam and north of the confluence of Lake Calumet and the Calumet River began in about 1967.

The period between 1978 and 1993 was marked by the initiation or expansion of sanitary landfilling at facilities in the vicinity of Lake Calumet, the west side of Gary, along the western flank of Blue Island, and about $1 \mathrm{mi}$ west of the State line south of Interstate $80 / 94$. The disposal facility for dredging spoil at Calumet Harbor (pl. 2) began operations in 1982. A former clay pit about $1 \mathrm{mi}$ south of the confluence of the Calumet Sag Channel and the Little Calumet River also was used for disposal of dredging spoil during this time. Infilling continued in Lake Michigan at Indiana Harbor and the northern part of Lake Calumet during this period. Small amounts of fill were deposited in an abandoned dock along the northern reach of the Calumet River.

Comparison of the date of fill deposition (pl. 3) with the types of fill deposited in an area (pl. 2) indicates trends in the disposal of many of the types of fill. These trends appear to be affected by changes in the regulations and technology governing waste disposal.

Discussions of waste-disposal activities by previous investigators (Colten, 1985; Crohurst and Veldee, 1926) indicate that, prior to 1922 , liquid and particulate wastes produced by steel manufacturing and other industrial activities were typically discharged untreated to the Calumet, 
Grand Calumet, and Little Calumet Rivers. Particulate matter included slaughterhouse refuse, raw sewage, and iron precipitates. Liquid wastes were primarily derived from steel manufacturing and petroleum processing. Liquid wastes produced as a by-product of steel manufacturing contained hundreds of tons of phenols, cyanide, napthalene, lubricating oils, sulfuric acid, and iron sulfate (Colten, 1985, p. 27, 45, 63).

After construction of the Calumet Sewage Treatment Plant in 1922, and subsequent construction of sewage-treatment plants for other area municipalities, raw sewage and effluent from a few industrial facilities received some treatment before discharge to surface water (Colten, 1985, p. 27). However, millions of gallons of sanitary sewage and industrial

wastewater were still discharged to Lake Michigan and the Calumet and Grand Calumet Rivers on an annual basis in the mid-1920's (Crohurst and Veldee, 1926, p. 64). There has been an increasing trend toward treatment of sanitary sewage and industrial wastewater prior to surface-water discharge since that time. This trend has accelerated since the mid-1960's with the passage of legislation designed to reduce the effects of sewage and industrial discharge to surface water. Wastewater treatment has lessened the amount of toxic materials that could be incorporated into river sediments, but produced concentrated chemical wastes and biological sludges requiring disposal.

The preferred method for disposal of industrial wastes and biological sludges from wastewatertreatment facilities, as well as municipal solid waste, is land disposal. Landfilling of municipal solid waste and industrial wastes in the Calumet region began in 1940 . Prior to the effective date of the Resource Conservation and Recovery Act in November 1980, codisposal of hazardous and nonhazardous wastes was accepted practice at many waste-disposal facilities in the study area, as well as the Nation in general. Prior to 1980 , the engineering requirements for the land disposal of waste materials were minimal, and site preparation for disposal was often limited to excavation of a pit for placement of wastes.

Comparison of the date of fill deposition (pl. 3) with the types of fill deposited in an area (pl. 2) indicates that most of the identified areas where industrial waste was deposited began to be filled in the period between 1965 and 1977. This corresponds to the period during which treatment of industrial wastewater accelerated and water disposal declined. It appears that industrial wastes were disposed of before
1965 at three sites near Lake Michigan in Indiana and two sites near the Calumet River in Illinois. The pre1965 sites in Indiana are located about midway between Gary Harbor and Indiana Harbor, at a facility located on the north side of the Grand Calumet River about 0.5 mi east of the Indiana Harbor Canal, and at the southeast end of the Gary Regional Airport (pl. 1) (Environmental Monitoring Systems Laboratory, 1991). The pre-1965 sites in Illinois are sites of gas manufacture and processing (Hanson Engineers, 1990; Barr Engineering, 1995). Deposition of industrial waste occurred subsequent to the initial period of fill deposition at the facilities near the Calumet Sewage Treatment Plant. Site documents indicate wastes were deposited between 1965 and 1977 at the two sites that border the plant (STS Consultants Ltd., 1982, p. 11).

Except for the landfill along the northern end of Lake Calumet, all of the identified sites of municipal waste disposal began to be filled after 1953. Most of these sites began operations after 1964. Municipal wastes were likely to have been used as fill before 1954; however, the locations at which these materials were deposited have not been well defined.

Land disposal of dredging spoil can be divided into three periods. Prior to the 1920's, dredging spoil was typically dumped indiscriminantly along the banks of the rivers from which the spoil was removed. Beginning in the 1920's, new regulations required that dredging spoils be disposed of in Lake Michigan approximately $12 \mathrm{mi}$ from shore (Colten, 1985, p. 39). Berms were constructed around the spoil remaining on the riverbanks during at least part of the period between 1928 and 1964. Disposal of dredging spoil in Lake Michigan was prohibited in the late 1960's (Colten, 1985, p. 65), necessitating a return to land disposal of dredging material. Since then dredging spoil has been placed in centralized disposal facilities designed to isolate the spoil from the environment. Many of these facilities were in the vicinity of Lake Calumet and have since become disposal sites for other types of fill.

Comparison of the date of fill deposition (pl. 3) with the types of fill deposited in an area (pl. 2) indicates that slag and other steel-industry wastes, ash, cinders, natural material, and construction debris typically have been disposed of by dumping onto vacant land and into lakes and wetlands for fill since 1870. Large amounts of these materials also have been used as foundation for streets, highways, and railroad lines since 1870 . Prior to 1954 , slag was disposed of 
throughout much of the study area. Since 1954, most of the slag has been disposed of in Lake Michigan in Indiana or in Lake Calumet in Illinois. Ash and cinder deposits were typically emplaced prior to 1928 as roadbed and fill near rail lines and in residential and industrial areas. Placement of ash and cinder has decreased, probably since the 1950's, as the use of coal for home heating and in railroad engines decreased. The only identified ash and cinder fill clearly resulting from steel manufacture was emplaced west of Wolf Lake after 1977. There are no apparent patterns to the disposal of construction debris and natural fill through time. These materials have been used as fill during the entire period of urban and residential development in this region. Construction debris has recently been used as fill near Lake Calumet.

\section{Effect on Ground-Water Quality}

Disposal of fill materials in lakes, wetlands, and on dry land over the past century has degraded ground-water quality in many areas and affected the viability of the remaining lakes and wetlands. A variety of compounds including major ions (especially chloride, sodium, and sulfate), total organic carbon, cyanide, metals, and volatile and semivolatile organic compounds were detected in ground water during prior investigations in the region (Illinois Environmental Protection Agency, 1986; Cravens and Zahn, 1990; Roadcap and Kelly, 1994; Duwelius and others, 1996). Ground-water-quality degradation was attributed to a variety of sources including fill deposits.

Each of the main fill types are composed of a mixture of materials capable of leaching constituents that could adversely affect surface- and ground-water quality. The potential effect on water quality from the fill depends on a number of factors including the type of fill, the amount of fill, the physical, chemical, and hydraulic properties of the fill and the surrounding geologic material, and the distance from the fill to surface water or ground water. It is important to remember, however, that water-quality degradation in any part of the study area can likely be attributed to a number of sources. The effect of fill on water quality at any given location must be determined through sitespecific studies.

Chemical analysis of the industrial wastes deposited in the study area indicates that these materials can be associated with a mixture of compounds, which can include volatile organic compounds (VOC's), semivolatile organic compounds (SVOC's), pesticides, polychlorinated biphenyls (PCB's), cyanide, and heavy metals (STS Consultants Ltd., 1982, p. 41; Ecology and Environment, Inc., 1990, Appendix I). These wastes can be a source of contaminants in soil, surface water, and ground water in the study area. Soil samples at one industrial wastedisposal site west of Lake Calumet contained more than $1,000 \mathrm{mg} / \mathrm{kg}$ of lead and chromium, more than $10 \mathrm{mg} / \mathrm{kg}$ of cyanide, more than $15,000 \mathrm{mg} / \mathrm{kg}$ of total pesticides, more than $80,000 \mathrm{mg} / \mathrm{kg}$ of PCB's, more than $150 \mathrm{mg} / \mathrm{kg}$ of VOC's, and more than $70,000 \mathrm{mg} / \mathrm{kg}$ of SVOC's (Ecology and Environment, Inc., 1990, table 4:9). VOC's including benzene, ethylbenzene, xylenes, toluene, and 4-methyl2-pentanone and SVOC's including phenolics, isophorone, napthalenes, and phthalates were detected in ground water at concentrations greater than $3,000 \mu \mathrm{g} / \mathrm{L}$ at this site.

In addition to nontoxic materials, such as food and yard waste, municipal solid waste typically contains small quantities of household wastes such as paint or motor oil. Other wastes, including biological sludges, waste oils, and inking wastes have been codisposed with municipal solid waste at several sanitary landfills in the study area (Warzyn Engineering, Inc., 1991, table 8a). Industrial wastes and municipal solid wastes also may have been disposed of outside the limits of some of the sanitary landfills prior to the initiation of sanitary landfilling practices (presence of a low-permeability liner, daily cover for trash, installation of leachate collection systems). Water in the vicinity of sanitary landfills and other municipal solid-waste disposal sites can have elevated alkalinity, specific conductance, and concentrations of chloride and sulfate. Lower concentrations of organic compounds including chlorinated alkanes and alkenes and aromatic hydrocarbons also can be associated with municipal solid wastes (Sabel and Clark, 1984, table 4; Nelson and Book, 1986, p. 29). The total concentration of VOC's in ground water from a well located next to the landfill along the northern edge of Lake Calumet was greater than $100 \mu \mathrm{g} / \mathrm{L}$ (Roadcap and Kelly, 1994, table 7).

Slag is composed primarily of silica $\left(\mathrm{SiO}_{2}\right)$, lime $(\mathrm{CaO})$, and a variety of metal oxides and other impurities produced from the manufacture of iron and steel (USX Corporation, 1985, p. 334). The 
pH of water in contact with slag fill can be greater than $11 \mathrm{pH}$ units in this area (Duwelius and others, 1996, p. 17). Ground-water samples from wells completed in or below slag deposits throughout the study area also may have elevated concentrations of ammonia, barium, chromium, potassium, tin, cyanide, silica, copper, mercury, vanadium, iron, and zinc (Cravens and Roadcap, 1991, p. 12; Duwelius and others, 1996, p. 34-42).

Although slag does not contain organic compounds, coal tar, processing water, and pickling liquors produced during the manufacture of steel were noted to have been codisposed with slag in the past (Colten, 1985). Gas-wash water from blast furnaces was noted to have been discharged directly on top of slag deposits at a steel-manufacturing facility once located near Calumet Harbor (Crohurst and Veldee, 1926, p. 18). It is likely that some components of the gas-wash water, pickling liquor, and coal tars remain in some of the slag fill. Pickling liquor can contain trace quantities of ferrous iron, chrome, lead, oil, and grease (U.S. Environmental Protection Agency, 1995, p. 28-29). Coal tar contains a variety of organic compounds including phenolics and napthalenes. Cyanide, at concentrations above the USEPA Maximum Contaminant Level of $200 \mu \mathrm{g} / \mathrm{L}$, has been detected in ground-water samples collected from wells open to slag and foundry sand (Duwelius and others, 1996, p. 39). Organic compounds, including phenolics, naphthalenes, benzene, toluene, and xylene, have been detected in ground-water samples from wells open to slag at concentrations greater than $1,000 \mu \mathrm{g} / \mathrm{L}$. Lower concentrations of fluorene, phenanthrene, acenaphthylene, and carbazole also were detected. No information was found that includes an analysis of the relation between ground-water quality and the period of slag deposition. However, it seems likely that slag emplaced after about 1970 , and perhaps earlier, would not have been codisposed with cyanide and organic compounds.

Dredging spoil is a mixture of nontoxic natural materials (primarily sand and silt) and may contain contaminants derived from industrial and sanitarysewage discharges, urban runoff, and discharge of contaminated ground water to surface water. The dredging spoil most likely to negatively affect water quality would probably be taken near a point of wastewater discharge and would have been emplaced prior to the beginning of wastewater treatment at that location. Predredged sediments collected from the
Calumet River in 1967 contained as much as $231,500 \mathrm{mg} / \mathrm{kg}$ of chemical-oxygen demand, $96,100 \mathrm{mg} / \mathrm{kg}$ of iron, $34,400 \mathrm{mg} / \mathrm{kg}$ of oil and grease, $1,199 \mathrm{mg} / \mathrm{kg}$ of organic nitrogen, $33.6 \mathrm{mg} / \mathrm{kg}$ of cyanide, $820 \mathrm{mg} / \mathrm{kg}$ of lead, $472 \mathrm{mg} / \mathrm{kg}$ of zinc, and $68 \mathrm{mg} / \mathrm{kg}$ of chromium (Joseph Jacobazzi, U.S. Army Corps of Engineers, written commun., 1994). These sediments may have been placed in the area north of the junction of the Calumet River and Lake Calumet, which is now used for treating biological sludges (pl. 2). Sediment samples collected from the Grand Calumet River, Indiana Harbor, or the Indiana Harbor Canal in 1983 contained more than $1,000 \mathrm{mg} / \mathrm{kg}$ of chromium and zinc, more than $100 \mathrm{mg} / \mathrm{kg}$ of anthracenes, pyrenes, chrysene, phenanthrene, copper, lead, nickel, and PCB's, and more than $10 \mathrm{mg} / \mathrm{kg}$ of acenapthene, arsenic, antimony, and cyanide (HydroQual, Inc., 1985, p. 3:35 and 3:37; U.S. Army Corp of Engineers, 1986, p. 18). Sediments sampled in 1992 at Indiana Harbor and the Indiana Harbor Canal contained up to $5,800 \mathrm{mg} / \mathrm{kg}$ of naphthalene and $10,000 \mathrm{mg} / \mathrm{kg}$ of total polycyclic aromatic hydrocarbons (Chuck Elly, U.S. Environmental Protection Agency, written commun., 1993). These compounds are typical components of steel-mill process waters and sewage discharge. However, sampling of ground water from four wells drilled into or through dredging spoil in the study area indicates that this material is not a source of large-scale groundwater contamination (Duwelius and others, 1996).

Ash and cinders are capable of leaching silica, sulfate, and metals to ground water and increasing the pH (Le Seur-Spencer and Drake, 1987, p. 519; Roadcap and Kelly, 1994, p. 43). Sampling of ground water from two wells drilled in an area of ash and cinder deposition does not indicate the materials are a source of organic compounds or cyanide in ground water. It is unclear if these deposits are contributing major ions to ground water.

Concrete construction debris may increase the pH of water (Roadcap and Kelly, 1994, p. 43) and preservatives in construction debris containing treated wood could potentially leach to ground water.

However, no information was found indicating that these fill types are contributing organic compounds, metals, or cyanide to ground water. It is unclear if these deposits are contributing major ions to ground water.

No indication was found of ground-water contamination derived from natural fill. However, 
natural fill, as well as ash and cinders and construction debris, is common in many areas where more toxic fill types also have been deposited. At one site north of the Grand Calumet River near the State line, samples of natural fill and construction debris contained more than $60 \mathrm{mg} / \mathrm{kg}$ of PCB's; more than $10 \mathrm{mg} / \mathrm{kg}$ of 12 different SVOC's, including phthalate and pyrene compounds; and detectable concentrations (less than $1 \mathrm{mg} / \mathrm{kg}$ ) of 7 compounds containing pesticides (Ecology and Environment, Inc., 1990, table 4-1). It is conceivable that unidentified industrial wastes, municipal solid waste, steel-industry wastes, or dredging spoil has been codisposed with ash and cinders, construction debris, and natural fill at other sites.

The fill deposits that are most likely to affect surface-water and ground-water quality are industrial wastes, municipal solid waste, and steel-industry wastes. These materials have the greatest potential to affect water quality where they are located near surface water or the Calumet aquifer (see fig. 6 and pl. 2) and were emplaced without adequate engineering controls designed to minimize contaminant migration. This particularly applies if the fill is saturated or is only a short distance above the saturated zone. This is to be expected because groundwater velocity data (Kay and others, 1996, p. 49) indicate that ground water in the Calumet aquifer, and compounds dissolved in ground water, can migrate by advective transport over $100 \mathrm{ft}$ in a year in some areas. Because the aquifer is composed largely of unreactive minerals like quartz and contains small amounts of organic carbon, it is probable that only small amounts of metals and organic compounds will adsorb or partition onto granular material. The maximum extent of ground-water contamination associated with a specific fill deposit is likely to be the distance between the deposit and the nearest point of ground-water discharge (sewers, surface-water bodies, pumping centers) in the direction of ground-water flow (see fig. 7 and pl. 2).

Fill deposits located above or within the upper part of the confining unit, especially deposits that are not near a surface-water body, have limited potential to affect water quality adversely (see fig. 6 and pl. 2). The geologic and hydraulic properties of the silt and clay deposits that compose the confining unit restrict contaminant migration. Ground-water velocity data (Kay and others, 1996, p. 49) indicate that ground water in the confining unit will typically migrate horizontally less than $4 \mathrm{ft}$ in 10 years. Because the confining unit contains clay minerals and organic carbon, metals and organic compounds will adsorb or partition onto the soils, further restricting their migration.

Ground water and the compounds dissolved in the ground water discharge to surface water in most of the study area. Over 10 percent of the total chemical load of ammonia, chromium, and cyanide to the Grand Calumet River in Indiana can be attributed to ground-water discharge (Fenelon and Watson, 1993). Although determining the effect of the fill deposits on the chemical load to the river was beyond the scope of this study, the contribution of fill deposits to groundwater-quality degradation indicates their potential to affect surface-water quality.

\section{SUMMARY AND CONCLUSIONS}

In October 1993, the U.S. Geological Survey, in cooperation with the U.S. Environmental Protection Agency, began a study to characterize the fill deposits in the Calumet region of northwestern Indiana and northeastern Illinois. The study was done to determine the type, location, thickness, and approximate date of deposition of the fill and to generally characterize the relation between fill type and ground-water quality. The study area includes northwestern Porter and northern Lake Counties in Indiana and southern Cook County in Illinois. Fill deposits cover more than $60 \mathrm{mi}^{2}$ of the region and have a total volume of $2.1 \times 10^{10} \mathrm{ft}^{3}$.

Thick, continuous fill deposits are present along the shore of Lake Michigan. Thinner, nearly continuous fill deposits also äre present from the area south and west of Lake Calumet to the Indiana Harbor Canal. The fill thickness in these areas ranges from absent in localized areas to over $100 \mathrm{ft}$. Extensive fill deposits also are located along the banks of the Little Calumet River, the Calumet Sag Channel, and along the streets, railroads, and highways. These deposits are typically less than $10 \mathrm{ft}$ thick. Isolated fill deposits of variable thickness are scattered throughout the area.

The fill in the study area is a heterogeneous mixture of steel-industry wastes, municipal solid wastes, dredging spoil, construction debris, ash and cinders, and natural material. Industrial wastes and biological sludges are found in small areas. 
Industrial wastes are concentrated near Lake Calumet and between the Indiana Harbor Canal and Gary Harbor. Industrial wastes also are present at scattered locations in Illinois and Indiana. Municipal solid wastes are in landfills concentrated near Lake Calumet and Blue Island. Landfills also are present south of the Calumet Sag Channel, in the southern part of the study area west of the State line, and at scattered locations in Indiana.

Steel-industry waste, mainly slag, is the most voluminous fill material in the area. Steel-industry wastes cover over $30.6 \mathrm{mi}^{2}$ of the region and have a volume of about $1.3 \times 10^{10} \mathrm{ft}^{3}$. Steel-industry wastes compose most of the fill along Lake Michigan, Wolf Lake, Lake George, and the western shore of Lake Calumet. Large amounts of slag also are along the Calumet and Little Calumet Rivers in Illinois. Slag is an important component of foundations for streets, bridges, highways, and railroads.

Dredging spoil is typically located along the banks of the rivers, in abandoned river channels, or centralized disposal areas. Large deposits of ash and cinders are present northeast of Lake Calumet, north of Lake George, east of the Indiana Harbor Canal, and west of Wolf Lake. Discontinuous deposits of ash and cinders are scattered throughout the region in residential and industrial areas. Most of the construction debris used as fill in this area was deposited near Lake Calumet and near the Grand Calumet River in the vicinity of the State line. Natural fill also was used to create land for industrial use near Burns Harbor. Construction debris, ash and cinders, and natural materials have been used extensively as fill for roadbeds.

Much of the fill deposited before 1902 was used as foundation for streets and railroad tracks. Fill also was deposited in Lake Calumet, along the shoreline of Lake Michigan in Chicago, in several of the smaller inland lakes, and along the northern part of the Calumet River.

Between 1902 and 1927, large amounts of fill were emplaced as industrial activity within the study area accelerated and expanded into Indiana. Dredging spoil was piled along the banks of the dredged rivers, and extensive fill deposits were emplaced in the areas of steel production along Lake Michigan and the Calumet and Little Calumet Rivers. The western half of Lake Calumet continued to be infilled.

A large increase in the land area used for fill deposition occurred between 1928 and 1953. In addition to numerous smaller areas, infilling of Lake Michigan and Lake Calumet continued during this period, and large-scale infilling began around Wolf Lake and Lake George. Between 1954 and 1964, the areas of fill deposition expanded from most of the areas where fill was deposited prior to 1954. Smaller land areas were used for fill between 1965 and 1977 as sanitary landfilling of municipal and industrial wastes expanded. The period between 1978 and 1993 was marked by continued expansion of sanitary landfilling of municipal and industrial wastes and some dredging spoil in the study area. Infilling of Lake Calumet and Lake Michigan has continued, although at a slower pace than in previous years.

Comparison of the date of fill deposition with the types of fill deposited in an area indicates that most of the identified areas where industrial waste was deposited were filled after 1964. Except for the landfill along the northern end of Lake Calumet, all of the identified sites of municipal waste disposal began to be filled after 1953. Ash and cinder deposits were typically emplaced prior to 1928 as roadbed and fill in residential and industrial areas. Ash and cinder deposits produced from steel manufacture near Wolf Lake were emplaced after 1977. Prior to the period between 1965 and 1977, dredging spoils were typically deposited along the bank of the river channel from which they were dredged. During this period, dredging spoils began to be disposed of by infilling clay pits and placing the spoils in centralized disposal facilities. Deposition of slag and other steel-industry wastes prior to 1955 occurred through much of the study area. Since 1955, most of the slag fill has been disposed of either in Lake Michigan or Lake Calumet.

Industrial wastes deposited in the study area can be associated with a mixture of volatile organic compounds, semivolatile organic compounds, pesticides, polychlorinated biphenyls, cyanide, and heavy metals. These compounds have contaminated soil, surface water, and ground water at several sites.

Municipal solid waste commonly consists of a mixture of organic material, household wastes, and other wastes. Water that has been in contact with these waste mixtures can contain high concentrations of chloride and sulfate and lower concentrations of organic compounds including chlorinated alkanes and alkenes, aromatic hydrocarbons, and semivolatile organic compounds.

Slag is composed of a number of constituents, primarily metal oxides. Other steel-industry wastes 
that were apparently codisposed with slag at some locations may have contained cyanide and volatile and (or) semivolatile organic compounds. Ground water in contact with slag and other steel-industry wastes may have high $\mathrm{pH}$ and elevated concentrations of metals, cyanide, and volatile and semivolatile organic compounds.

Dredging spoil is a mixture of nontoxic natural materials and potentially toxic materials derived from industrial and sanitary-sewage discharges, urban runoff, and discharge of contaminated ground water. Dredging spoils can have elevated concentrations of chemical-oxygen demand, total Kjeldahl nitrogen, semivolatile organic compounds, metals, and polychlorinated biphenyls. Limited sampling of ground water does not indicate that dredging spoil is a source of widespread ground-water contamination in this region.

Ash and cinders can leach silica, sulfate, and metals to ground water and increase $\mathrm{pH}$. Concrete construction debris may increase the $\mathrm{pH}$ of water. These materials, along with natural fill, do not appear to be a source of organic compounds or cyanide in ground water in the study area but may be sources of major ions. More toxic types of fill also may be located in these areas. Fill, particularly industrial liquid wastes, municipal solid waste, and steelindustry wastes, located above or within the Calumet aquifer and (or) near a surface-water body is likely to have the greatest effect on surface water and ground water. Fill located above or within the confining unit should not appreciably affect ground-water quality under most circumstances.

\section{REFERENCES CITED}

Baker/TSA, Inc., 1988, Ground water assessment plan, National Steel Corporation, Midwest Steel Division, Portage, Ind.: Unpublished report on file in Chicago, Ill. at the U.S. Environmental Protection Agency, (various pagination).

Barr Engineering, 1995, Phase 1 site investigation report, 110th street site, People's Gas Light and Coke Company: prepared for the Illinois Environmental Protection Agency, Springfield, Ill., 40 p.

Black and Veetch, 1993, Expanded site inspection, site specific implementation plan for Alburn: Prepared for the Illinois Environmental Protection Agency, Springfield, Ill., 8 p.
Bretz, H.J., 1939, Geology of the Chicago region, part I-General: Illinois State Geological Survey Bulletin no. 65, part 1, 118 p.

Brown, B.C., 1972, The mineral industry in Indiana: U.S. Bureau of Mines Minerals Yearbook, 1970, v. II, p. 253-271.

Carlson Environmental, Inc., 1995, RCRA facility investigations phase I report, clean harbors of Chicago, Inc. facility: prepared for the Illinois Environmental Protection Agency, Springfield, Ill., 6 v.

Colten, C.E., 1985, Industrial wastes in the Calumet area, 1869-1970-An historical geography: Savoy, Ill., Illinois Hazardous Waste Research and Information Center Report RR 001, 124 p.

Cook, S.G., and Jackson, R.S., 1978, The Bailey area of Porter County, Indiana: Robert Jackson and Associates, Evanston, Ill., 110 p.

Cravens, S.J., and Zahn, A.L., 1990, Ground-water quality investigation and monitoring program design for the Lake Calumet area of southeast Chicago: Savoy, Ill., Illinois Hazardous Waste Research and Information Center SWS Contract Report 496, 112 p.

Cravens, S.J., and Roadcap, G.S., 1991, Shallow groundwater quality investigation bordering Lake Calumet: Springfield, Ill., Interim Report prepared for the Illinois Department of Energy and Natural Resources, $24 \mathrm{p}$.

Crohurst, H.R., and Veldee, M.V., 1926, Report on an investigation of the pollution of Lake Michigan in the vicinity of South Chicago and the Calumet and Indiana Harbors: United States Public Health Service Report, $67 \mathrm{p}$.

Dull, C.E., Metcalf, H.C., and Williams, J.E., 1958, Modern chemistry: New York, Holt, Rinehart and Winston, Inc., 694 p.

Duwelius, R.F., Kay, R.T., and Prinos, S.T., 1996, Groundwater quality in the Calumet region of northwestern Indiana and northeastern Illinois: U.S. Geological Survey Water-Resources Investigations Report 95-4244, $179 \mathrm{p}$.

Ecology and Environment, Inc., 1990, Special study report of U.S. Scrap: Chicago, Ill., prepared for the U.S. Environmental Protection Agency, 253 p. 1993, Site assessment report for the H. Baristow Company site, USEPA ID: IND980679021: Unpublished report on file in Chicago, Ill., at the U.S. Environmental Protection Agency, sections 1-4, (various pagination).

Eldridge Engineering Associates, 1990, Site closure documents, Sexton-Lansing landfill: Springfield, Ill., prepared for the Illinois Environmental Protection Agency, $53 \mathrm{p}$.

Environmental Monitoring Systems Laboratory, 1991, Land use and site maps-NW Indiana discovery inventory: 
Chicago, Ill., Prepared for the U.S. Environmental

Protection Agency, Region 5, 15 p.

Fenelon, J.M., and Watson, L.R., 1993, Geohydrology and water quality of the Calumet aquifer in the vicinity of the Grand Calumet River/Indiana Harbor Canal, northwestern Indiana: U.S. Geological Survey WaterResources Investigations Report 92-4115, 151 p.

Fenneman, N.M., 1938, Physiography of the eastern United States: New York, McGraw-Hill, 691 p.

Geraghty and Miller, 1995, Phase III, Ground water quality assessment program: prepared for US Steel, Gary, Ind., by Geraghty and Miller, Inc., Chicago, Ill.

Geosciences Research Associates, Inc., 1987, Remedial investigations of Midwest Solvent Recovery, Inc., (Midco I), Gary, Indiana, public comment draft: Unpublished report on file in Chicago at the U.S. Environmental Protection Agency, sections 1-4, (various pagination).

1988, Remedial investigations of Midwest Waste Disposal Co., Inc., (Midco II), Gary, Indiana, public comment draft: Unpublished report on file in Chicago at the U.S. Environmental Protection Agency, sections $1-4$, (various pagination).

Gray, H.H., 1989, Quaternary geologic map of Indiana: Indiana Department of Natural Resources, Geological Survey Miscellaneous Map 49.

Greeman, T.K., 1995, Water levels in the Calumet aquifer and their relation to surface-water levels in northern Lake County, Indiana, 1985-92: U.S. Geological Survey Water-Resource's Investigations Report 94-4110, $61 \mathrm{p}$.

Grohmann, A.T., and Liljenerantz, G.A.M., 1902, Map showing Calumet River District-Illinois \& Indiana: Corps of Engineers, U.S. Army, scale: 1 inch $=1$ mile.

Hanson Engineers, 1990, Environmental site assessment gas distribution facility archives, Chicago, Illinois: prepared for People's Gas Light and Coke Company, Chicago, Ill., 45 p.

Hartke, E.J., Hill, J.R., and Reshkin, M., 1975, Environmental geology of Lake and Porter Counties, Indiana-An aid to planning: Bloomington, Ind., Indiana Department of Natural Resources Geological Survey Special Report 11, 57 p.

Houston, D.C., comp., 1872, (Map of) Calumet-Grand Calumet Rivers-Illinois and Indiana: Corps. of Engineers, U.S.A., Calumet River series A, no. 1, scale: 1 inch $=1$ mile.

HydroQual, Inc., 1985, Grand Calumet river wasteload allocation study: Indianapolis, Ind., Report to the Indiana State Board of Health, 198 p.

Illinois Environmental Protection Agency, 1986, The Southeast Chicago area environmental pollution and public health impacts: Springfield, Ill., Illinois
Environmental Protection Agency Environmental Programs Report IEPA/ENV/86-008, 144 p.

Indiana Department of Natural Resources, 1979, An inventory of man-made land along the shoreline of Lake Michigan: Indiana State Planning Services Agency Technical Report no. 304, 24 p.

Integrated Site, Inc., 1990, Big Marsh wetland assessment and planning project, progress report \#1: Prepared for Waste Management of Illinois, Inc., Oak Brook, Ill., $86 \mathrm{p}$.

Kay, R.T., Duwelius, R.F., Brown, T.A., Micke, F.A., Witt-Smith, C.A., 1996, Geohydrology, water levels and directions of flow, and occurrence of lightnonaqueous-phase liquids on ground water in northwestern Indiana and the Lake Calumet area of northeastern Illinois: U.S. Geological Survey WaterResources Investigations Report 95-4253, 84 p.

Law Environmental, Inc., 1993, Description of current conditions, Inland Steel Corporation Indiana harbor works: Chicago, Ill., Document prepared for the U.S. Environmental Protection Agency, 4 volumes.

Leighton, M.M., Ekblaw, G.E., and Horberg, C.L., 1948, Physiographic divisions of Illinois: Journal of Geology, v. 56, no. 1, p. 16-33.

Le Seur-Spencer, L., and Drake, L.D., 1987, Hydrogeology of an alkaline fly ash landfill in eastern Iowa: Ground Water, v. 25, no. 5, p. 519-526.

Lillesand, T.M., and Kiefer, R.W., 1987, Remote sensing and image interpretation: New York, John Wiley and Sons, $721 \mathrm{p}$.

Malott, C.A., 1922, The physiography of Indiana, in Logan, N.W., and others, Handbook of Indiana geology: Indiana Department of Conservation Division of Geology Publication 21, p. 112-124.

Mayer, A.H., 1950, (Map of) Calumet region-northwest Indiana and northeast Illinois-Vegetation of the fundament (as of 1830): Papers of the Michigan Academy of Science, Arts, and Letters, v. 36, scale: 1 inch $=2.5$ miles.

McLaren Hart Environmental Engineering Corporation, 1993, Phase I RI report for the PMC Specialties, Inc. site, Chicago, Illinois: Springfield, Ill., Report prepared for the Illinois Environmental Protection Agency, 582 p.

Moore, P.A., 1959, The Calumet Region-Indiana's last frontier: Indiana Historical Collections, v. 39, Indiana Historical Bureau, $685 \mathrm{p}$.

National Oceanic and Atmospheric Administration, 1991, Climatological data annual summary-Illinois: National Oceanic and Atmospheric Administration, v. 96 , no. 13.

Nelson, B.R., and Book, P.R., 1986, Monitoring for volatile organic hydrocarbons at Minnesota sanitary landfills: Proceedings of the Ninth Annual Madison Waste 
Conference, Madison, Wis., September 9-10, 1986, p. 25-26.

Roadcap, G.S., and Kelly, W.R., 1994, Shallow groundwater quality and hydrogeology of the Lake Calumet area, Chicago, Illinois: Interim Report Prepared for the Illinois Department of Energy and Natural Resources, $64 \mathrm{p}$.

Rosenshein, J.S., 1961, Groundwater resources on northwestern Indiana, preliminary report, Lake County: Indiana Department of Natural Resources Bulletin no. 10, 229 p.

Ross, P.E., Henebry, M.S., Risatti, J.B., Murphy, T.J., and Demissie, M., 1988, A preliminary environmental assessment of the contamination associated with Lake Calumet, Cook County, Illinois: Illinois Department of Energy and Natural Resources Hazardous Waste Research and Information Center Report RR 019, $142 \mathrm{p}$.

Sabel, G.V., and Clark, T.P., 1984, Volatile organic compounds as indicators of municipal solid waste leachate contamination: Waste Management and Research, v. 2, p. 119-130.

Salisbury, R.D., and Alden, W.C., 1899, The geography of Chicago and its environs: Bulletin of the Geographic Society of Chicago, no. 1, $64 \mathrm{p}$.

Schneider, A.F., 1966, Physiography, in Natural Features of Indiana: Crawfordsville, Ind., Alton F. Lindsey ed., Indiana Academy of Science Symposium, April 2223, 1966, p. 40-56.

Schneider, A.F., and Keller, S.J., 1970, Geologic map of the $1 \times 2$ Chicago quadrangle, Indiana, Illinois, and Michigan showing bedrock and unconsolidated deposits: Indiana Department of Natural Resources, $1 \mathrm{p}$.

STS Consultants Ltd., 1980, Ground water contamination evealuation, Steel Container Corporation: prepared for the U.S. Environmental Protection Agency, Chicago, III., $57 \mathrm{p}$.

1982, Contamination survey, U.S. Scrap Corporation, Penn Central Corporation, Chicago, Illinois: Springfield, Ill., Prepared for the Illinois Attorney General, Environmental Division, 2 volumes.

1983, Ground water monitoring well installation, Sherwin Williams chemical company: prepared for the Illinois Environmental Protection Agency, Springfield, Ill., 13 p.
U.S. Army Corps of Engineers, 1839, Map of Calumet Region, 1 p.

_-1968, Dredging and water quality in the Great Lakes: Prepared for the U.S. Army Corps of Engineers, Chicago District, v. 12, 200 p.

-1986, Draft environmental impact statement, Indiana Harbor confined disposal facility and maintenance dredging, Lake County, Indiana: prepared for the U.S. Army Corps of Engineers, Chicago District, $273 \mathrm{p}$.

1987, Fact sheet: Chicago area CDF: Prepared for the U.S. Army Corps of Engineers, Chicago District, 12 p.

U.S. Congress, Senate, 1882, Lake Calumet area 1881: Executive Document, First Session, 1882, no. 77, 75 p.

U.S. Environmental Protection Agency, 1995, Draft, RCRA corrective action order-USX Corporation, Gary Works: Chicago, Ill., U.S. Environmental Protection Agency, Region 5, 102 p.

USX Corporation, 1985, The making, shaping, and treating of steel: Pittsburgh, Pa., Herbick and Held, 1572 p.

Warzyn Engineering, Inc., 1987, Agency review draft, remedial investigations report, Ninth Avenue Dump, Gary, Indiana: Omaha, Nebr., U.S. Army Corps of Engineers, Contract No. DAWC 45-86-c-0002, acting for the U.S. Environmental Protection Agency, (various pagination).

-1991, Environmental inventory update and remediation costs for Lake Calumet Airport, Lake Calumet Airport feasibility study: Chicago, Ill., Prepared for the Chicago Department of Aviation, $30 \mathrm{p}$.

Watson, L.R., Shedlock, R.J., Banaszak, K.J., Arihood, L.D., and Doss, P.K., 1989, Preliminary analysis of the shallow ground-water system in the vicinity of the Grand Calumet River/Indiana Harbor Canal, northwestern Indiana: U.S. Geological Survey Open-File Report 88-492, 45 p.

Weston-SPER, 1983, Site assessment and emergency action plan for Paxton Avenue Lagoon, Chicago, Ill.: prepared for the Illinois Environmental Protection Agency, Springfield, Ill., 26 p.

Willman, H.B., 1971, Summary of the geology of the Chicago area: Illinois State Geological Survey Circular 460, $77 \mathrm{p}$. 


$$
d x
$$




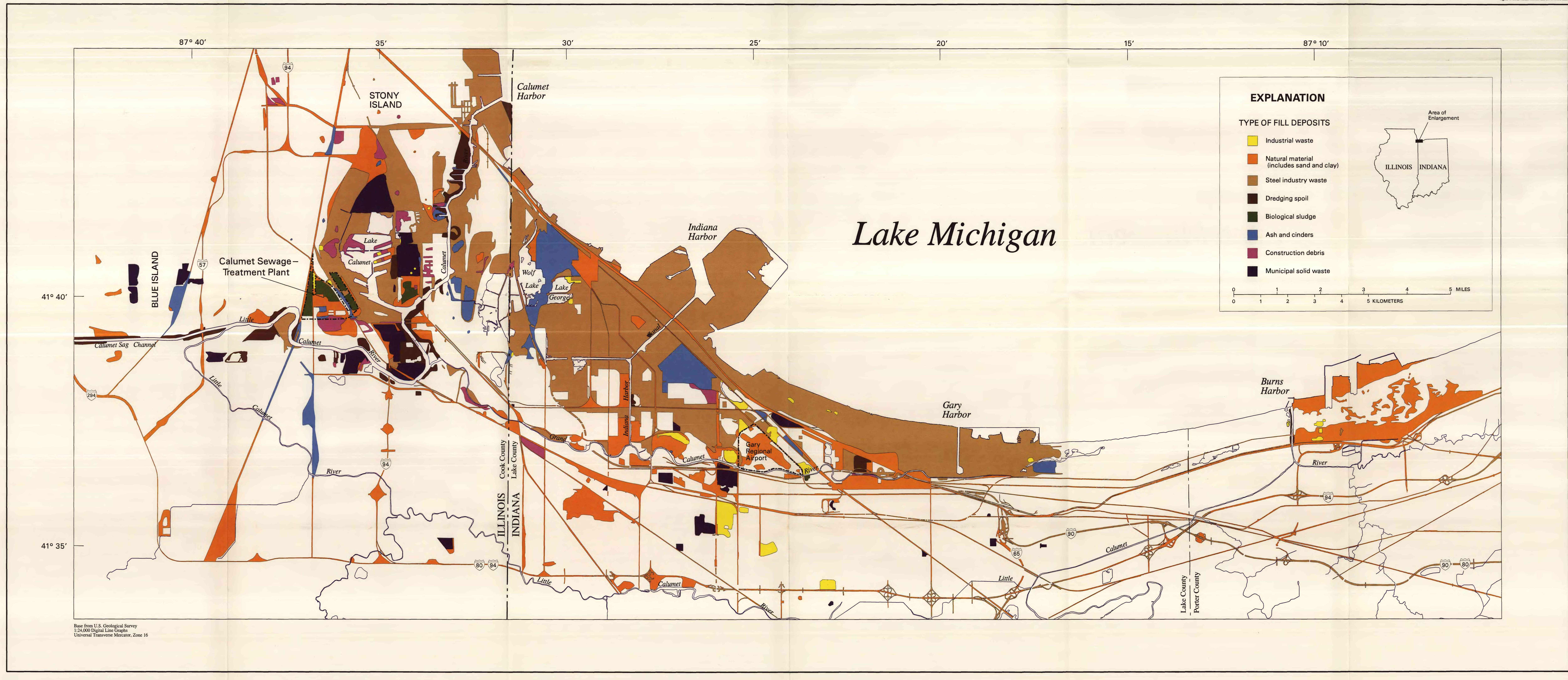




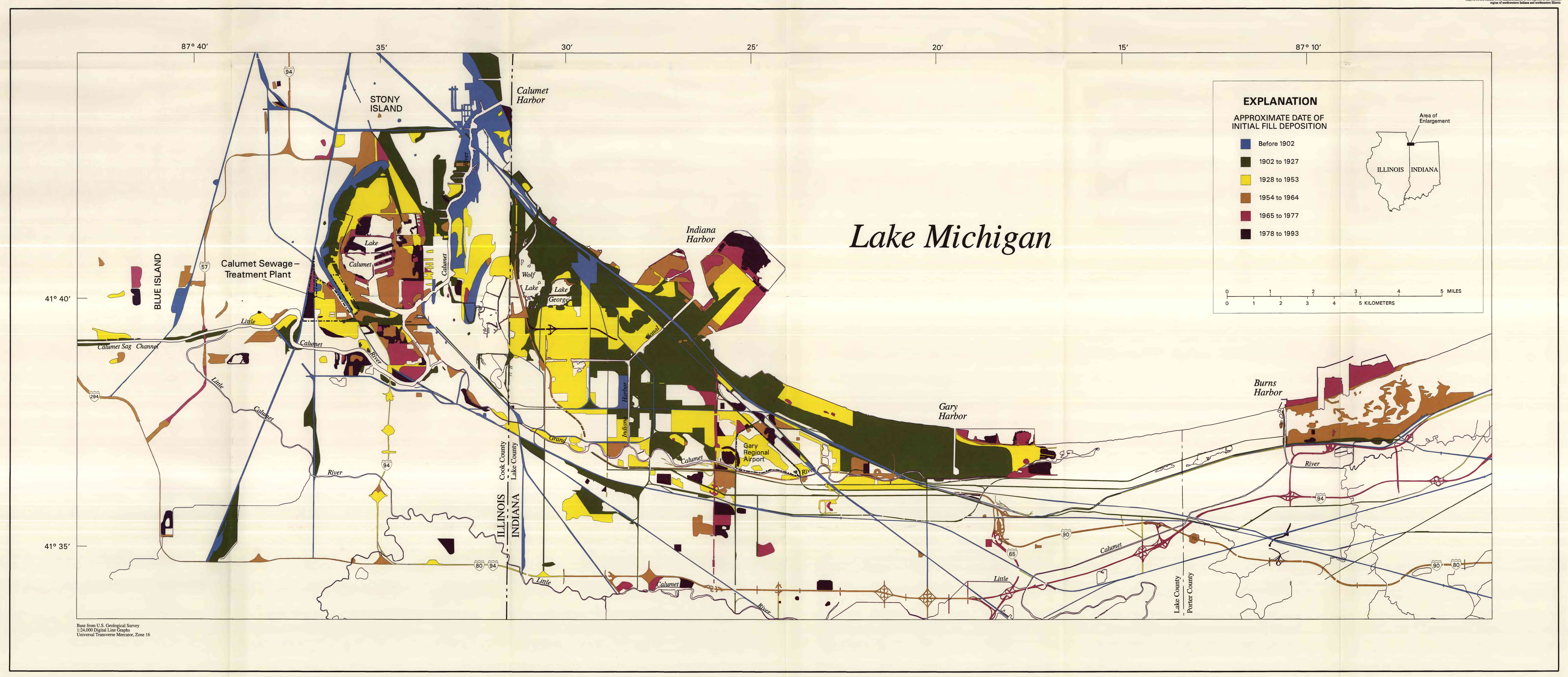

